PNL-6572

UC-95d

$1 \delta \cdot T$

\title{
Trends in Household Energy Conservation Attitudes and Behaviors in the Northwest: 1983-1987
}

R. W. Schultz

B. M. Bailey

R. O. Weijo, Project Manager

June 1988

Prepared for

the Bonneville Power Administration

Office of Conservation and Power Resources under a Related Services Agreement with the U.S. Department of Energy Contract DE-AC06-76RLO 1830

Pacific Northwest Laboratory Operated for the U.S. Department of Energy by Battelle Memorial Institute 


\title{
DISCLAIMER
}

This report was prepared as an account of work sponsored by an agency of the United States Government. Neither the United States Government nor any agency thereof, nor Battelle Memorial Institute, nor any or their employees, makes any warranty, expressed or implied, or assumes any legal liability or responsibility for the accuracy, completeness, or usefulness of any information, apparatus, product, or process disclosed, or represents that its use would not infringe privately owned rights. Reference herein to any specific commercial product, process, or service by trade name, trademark, manufacturer, or otherwise does not necessarily constitute or imply its endorsement, recommendation, or favoring by the United States Government or any agency thereof, or Battelle Mernorial institute. The views and opinions of authors expressed herein do not necessarily state or reflect those of the United States Government or any agency thereof, or Battelle Memorial Institute.

\author{
PACIFIC NORTHWEST LABORATORY \\ operated by \\ BATTELLE MEMORIAL INSTITUTE \\ for the \\ UNITED STATES DEPARTMENT OF ENERGY \\ under Contract DE-ACO6-76RLO 1830
}

\begin{tabular}{|c|c|}
\hline $\begin{array}{r}\text { Printed in the } \\
\text { National Tech } \\
\text { United States } \\
5285 \\
\text { Springfi }\end{array}$ & $\begin{array}{l}\text { of America } \\
\text { tion Service } \\
\text { i Commerce } \\
\text { ad } \\
22761\end{array}$ \\
\hline & \\
\hline & \\
\hline Pages & $\begin{array}{l}\text { Price } \\
\text { Codes }\end{array}$ \\
\hline$\infty 01-025$ & $\mathrm{~A} 02$ \\
\hline $026-050$ & $\mathrm{~A} 03$ \\
\hline $051-075$ & AOA \\
\hline $076-100$ & AOS \\
\hline $101-125$ & $A D 6$ \\
\hline $126-150$ & $\mathrm{~A} 07$ \\
\hline $151-175$ & $A 08$ \\
\hline $176-200$ & AOP \\
\hline $201-225$ & $A 010$ \\
\hline $226-250$ & A011 \\
\hline $251-275$ & $\mathrm{~A} 012$ \\
\hline $276-300$ & A013 \\
\hline
\end{tabular}


PNL -6572

UC-95d

TRENDS IN HOUSEHOLD ENERGY CONSERVATION ATTITUDES AND BEHAVIORS IN

THE NORTHWEST: 1983 - 1987

R. W. Schultz

B. M. Bailey

R. 0. Weijo, Project Manager

June 1988

Prepared for

the Bonneville Power Administration

Office of Conservation and Power Resources

under a Related Services Agreement

with the U.S. Department of Energy

Contract DE-ACO6-76RLO 1830 


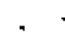

'

" 


\section{EXECUTIVE SUMMARY}

The objective of this report is to present the results of a 1987 telephone survey on attitudes and behaviors toward energy conservation and to compare them with the results of similar surveys in 1983 and 1985 . The surveys were conducted in the Bonneville Power Administration (BPA) service area: Washington, Oregon, Idaho and Western Montana. Data collected during the surveys were analyzed by Pacific Northwest Laboratory (PNL) to assist the $B P A$ in its energy conservation program planning, design, and marketing.

\section{PERCEPTIONS OF ENERGY CONSERVATION AND AFFILIATED INSTITUTIONS}

Asked to rate major socioeconomic issues about which they were "very concerned," survey respondents indicated the following, ranked in descending order: crime, cost of energy, inflation, energy conservation, unemployment, and energy use in the home. Concern over energy-related issues has generally remained at a constant level over the study period.

Respondents believe that investing in energy conservation saves them money and enhances the comfort and value of their homes. Since 1983 consumers have become more familiar with the BPA and their local electric utility and are more inclined to believe energy conservation information provided by these agencies.

\section{ENERGY CONSERVATION ACTIONS}

Respondents were asked about their past use and their possible future use of both building shell and building equipment enhancements. Building she11 enhancements are weatherproofing, storm/thermal pane windows, basement/floor/crawlspace insulation, outside wall insulation, roof/attic insulation, and storm/insulated doors. Building equipment enhancements are heat pumps, auto/setback thermostats, woodstove/furnaces, water heater solar panels, and heat pump water heaters.

Each of the shell enhancements has been widely adopted and, according to the 1987 data, the likelihood of further investment is declining. One 
exception is storm/insulated doors, which appear to be the energy conservation measure most likely to be installed in the future.

Building equipment enhancements have not penetrated the market to the same extent as have building shell enhancements. The 1987 survey shows that building equipment enhancements such as heat pumps, water heater solar panels, and heat pump water heaters are "likely to be installed in the next 2-3 years" in roughly one out of every ten homes. This response is similar to the response indicated in 1983 and 1985. Woodstoves/furnaces continue to be a measure likely to be installed in the near future.

\section{PRIMARY HEATING FUELS AND FUEL SWITCHING}

Electricity increased its market share as a primary heating fuel during the course of the study, reaching a level of nearly half of all homes by 1987. Wood is now the primary heating fuel in $22 \%$ of the homes in the region. Natural gas and oil appear to have maintained a fairly constant market share.

Between 1983 and 1985, an estimated 275,000 households switched their primary heating fuel. Approximately 135,000 households switched between 1985 and 1987. Electricity was dropped as the primary heating fuel about half of the time. Natural gas appears less likely to be dropped as a primary fuel; this was not the case in the 1983 to 1985 period when wood held much public favor.

The primary heating fuel adopted most of ten throughout the study period was wood, followed by electricity. Wood was adopted for nearly $60 \%$ of the fuel switches in the early period, but has since fallen to $46 \%$. The reduction in wood has meant that electricity, natural gas and oil have each picked up shares of the "new primary fuel" market.

\section{MARKET SEGMENTATION}

The market segment specifically addressed here is the first-tier prospects: those consumers who are most likely to make investments in conservation. First-tier prospects have installed at least two ECMs in the past and indicated they are likely to install at least one item in the next two or 
three years. While the responses of second-tier prospects and nonprospects tend to be similar to those of the first-tier prospects, their intention to invest is lower.

First-tier prospects tend to be concerned about energy issues. Important market program themes for first-tier prospects appear to be "energy conservation saves money, and enhances the comfort and value of the home." In the 1987 survey, approximately $80 \%$ of the first-tier prospects agreed that these were primary motivations for investing in ECMs.

This group has invested heavily in building shell enhancements such as weatherproofing and insulation. Thus, further penetration of this type of ECM may be limited. Building equipment enhancements such as heat pumps, water heater solar panels, and heat pump water heaters are "likely to be installed in the next 2-3 years" in roughly two out of every ten first-tier prospects homes. Woodstoves/furnaces and auto/setback thermostats continue to be a measures likely to be installed in the near future. 


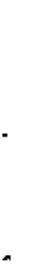




\section{CONTENTS}

EXECUTIVE SUMMARY $\ldots \ldots \ldots \ldots \ldots$ i $\ldots$ i

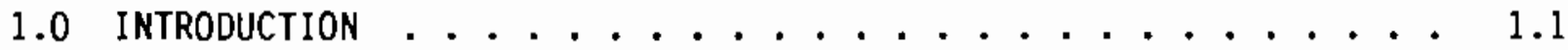

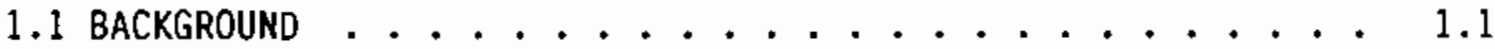

1.21987 SURVEY AND SAMPLE DESCRIPTION . . . . . . . 1.2

1.3 REPORT FORMAT . . . . . . . . . . . . . . . 1.3

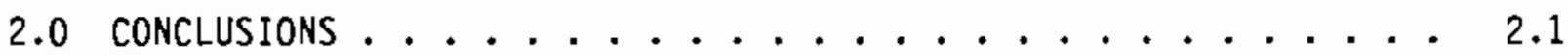

2.1 PERCEPTIONS OF ENERGY CONSERVATION AND AFFILIATED

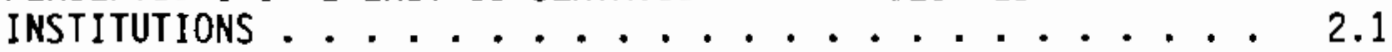

2.2 ENERGY CONSERVATION ACTIONS . . . . . . . . . . . 2.2

2.3 PRIMARY HEATING FUELS AND FUEL SWITCHING . . . . . . 2.3

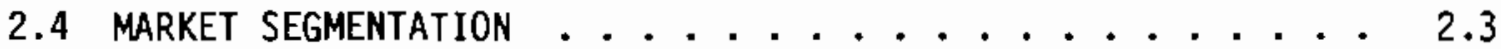

2.4.1 Perceptions of Energy Conservation: FirstTier Prospects .............. 2.4

2.4.2 Installed Energy Conservation Measures:

First-Tier Prospects . . . . . . . . 2.5

2.4.3 Intended Energy Conservation Measure Investment:

First-Tier Prospects . . . . . . . . 2.5

3.0 PERCEPTIONS OF ENERGY CONSERVATION AND AFFILIATED

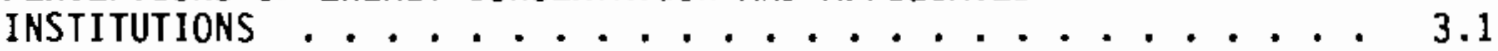

3.1 ENERGY CONSERVATION AS A MAJOR SOCIOECONOMIC

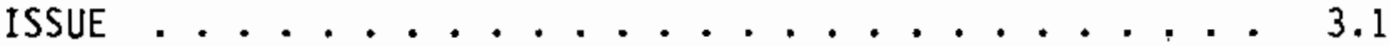

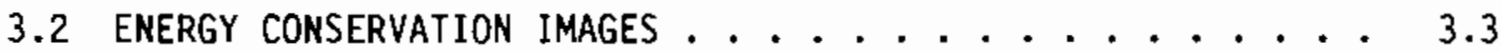

3.3 PERCEPTIONS OF ENERGY INSTITUTIONS . . . . . . . . . 3.4

4.0 ENERGY CONSERVATION ACTIONS . . . . . . . . . . . . 4.1

4.1 INSTALLED CONSERVATION MEASURES $\ldots \ldots \ldots . \ldots . \ldots . \ldots$

4.1.1 Building Shell Enhancements .......... 4. 4.1 
4.1.2 Building Equipment Enhancements ......... 4.1

4.2 INTENDED FUtURE CONSERVATION INVESTMENT . . . . . . 4.3

4.2.1 Building Shell Enhancements ........... 4.4

4.2.2 Building Equipment Enhancements ......... 4.4

5.0 PRIMARY HEATING FUELS AND FUEL SWITCHING . . . . . . . . 5.1

5.1 PRIMARY HEATING FUELS ........................ 5.1

5.2 PRIMARY HEATING FUELS DROPPED ................. 5.1

5.3 PRIMARY HEATING FUELS ADOPTED . . . . . . . . . 5.1

6.0 MaRKet Segmentation . . . . . . . . . . . 6.1

6.1 MARKET SEGMENTS AND PROSPECT GROUPS .......... 6.1

6.2 PERCEPTIONS OF ENERGY CONSERVATION: FIRST-TIER

6.3 INSTALLED ENERGY CONSERVATION MEASURES: FIRST-
TIER PROSPECT GROUP . . . . . . . . . . . . . . . 6.7

6.3.1 Installed Building Shell Enhancements:
First-Tier Prospects . . . . . . . 6.7

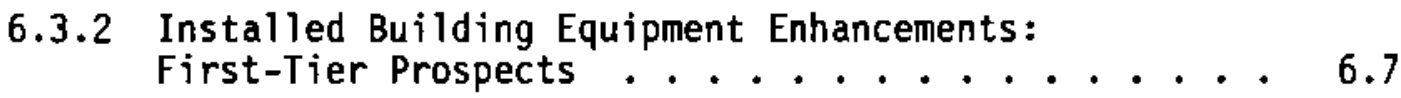

6.4 INTENDED ENERGY CONSERVATION MEASURE INVESTMENT:

FIRST-TIER PROSPECTS . ............ 6.9

6.4.1 Intended Building Shell Enhancements:

First-Tier Prospects .......... 6.9

6.4.2 Intended Building Equipment Enhancements:
First-Tier Prospects ........ 6.9

6.5 OTHER PROSPECT GROUPS ........................ 6.10

6.5 .1 Population Characteristics ......... 6.11

6.5.2 Perceptions of Energy Conservation ....... 6.12

6.5.3 Installed and Intended-to-Install Energy $\ldots . . . .6 .12$ 
APPENDIX A - CONTINGENCY TABLES FOR 1983, 1985, AND 1987

SURVEY RESULTS ........................... A

APPENDIX B - SAMPLE WEIGHTS ............... B.1

APPENDIX $c$ - TESTING PROCEDURE AND TEST RESULTS . . . . . . . c.1

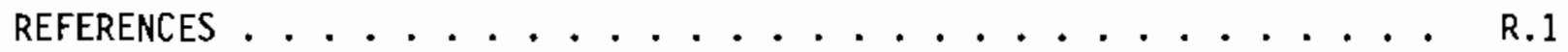

BIBLIOGRAPHY ............................ 


\section{FIGURES}

3.1 Issues Consumers are "Very Concerned" About . . . . . . . 3.2

3.2 Energy Conservation Statements Consumers Agree With . . . . . 3.2

3.3 Perceptions of the Local Electric Utility . . . . . . . . 3.2

3.4 Perceptions of the Bonneville Power Administration . . . . 3.2

4.1 Installed Shell Enhancements . . . . . . . . . 4.2

4.2 Installed Equipment Enhancements . . . . . . . . 4.2

4.3 Intended Investment in Shell Enhancements . . . . . . . 4.2

4.4 Intended Investment in Equipment Enhancements . . . . . . . 4.2

5.1 Primary Heating Fuels . . . . . . . . . . . 5.2

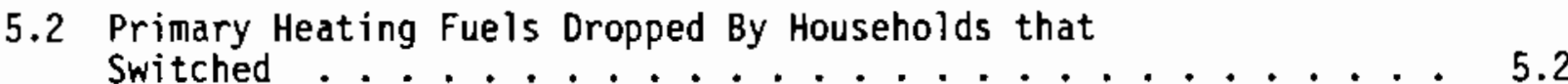

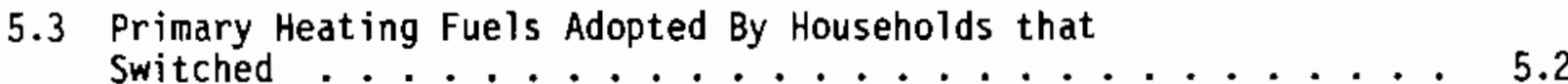

6.1 Residential Market Segmentations . . . . . . . . 6.2

6.2 Prospect Group Households . . . . . . . . . . . . 6.2

6.3 Age: First-Tier Prospects ............. 6.4

6.4 Annual Household Income: First-Tier Prospects . . . . . . 6.4

6.5 Type of Dwelling: First-Tier Prospects . . . . . . . 6.4

6.6 Size of Household: First-Tier Prospects . . . . . . . . 6.4

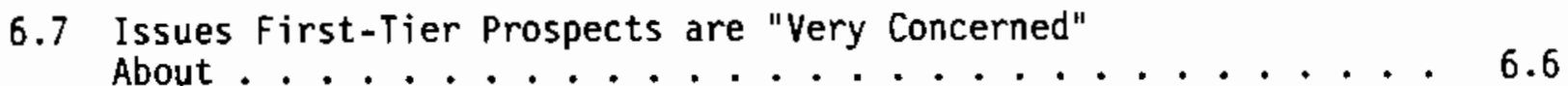

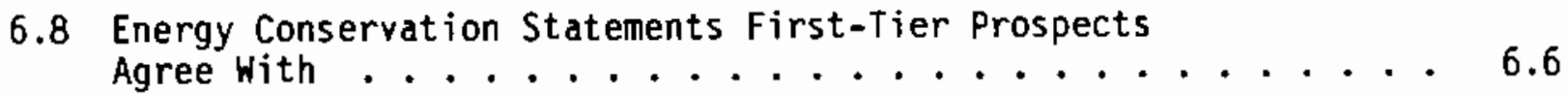

6.9 Installed Shell Enhancements: First-Tier Prospects . . . . 6.8 
6.10 Installed Equipment Enhancements: First-Tier Prospects . . . 6 6.8

6.11 Intended Investment in Shell Enhancements: First-Tier Prospects...................... 6.8

6.12 Intended Investment in Equipment Enhancements: First-Tier Prospects ................... 6.8

6.13 Installed Shell Enhancements: Second-Tier Prospects . . . . . 6.13

6.14 Installed Equipment Enhancements: Second-Tier Prospects . . . 6.13

6.15 Intended Investment in She11 Enhancements: Second-Tier Prospects . . . . . . . . . . . . . 6.13

6.16 Intended Investment in Equipment Enhancements: Second-Tier Prospects .................. 6.13

6.17 Installed Shell Enhancements: Nonprospects . . . . . . . 6.14

6.18 Installed Equipment Enhancements: Nonprospects . . . . . . 6.14

6.19 Intended Investment in She11 Enhancements: Nonprospects . . 6.14

6.20 Intended Investment in Equipment Enhancements: Nonprospects . 6.14 


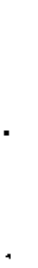




\subsection{INTRODUCTION}

This study, conducted by Pacific Northwest Laboratory (PNL), tracks household attitudes and behaviors in the Pacific Northwest during the period 1983 to 1987 . The analysis was conducted for the Bonneville Power Administration (BPA) to facilitate its energy conservation program planning, design, and marketing.

\subsection{BACKGROUND}

From 1983 to 1987 the BPA sponsored three independent surveys designed to assess the marketing environment for energy conservation programs and activities in the Pacific Northwest. All three surveys were stratified random telephone surveys of the BPA service area, and all three were analyzed for the BPA by PNL.

The first survey, which was part of the Phase I study conducted by PNL, was administered in 1983. It was fielded to 500 households from four geographic divisions: Western Washington; Western Oregon; Eastern Oregon and Southern Idaho; and Eastern Washington, Northern 1daho and Western Montana. A total sample size of 2000 households was obtained from the BPA service region. The Phase I survey samples are discussed in RMH (1984).

A second survey, conducted as part of the Phase II study, was fielded in 1985. This survey, with a sample size of 1058 households, covered the same regions in proportions similar to those defined in the Phase I effort. The Phase 1 I survey was designed not only to test certain hypotheses about attitudes, behaviors, and conservation practices of households, but also to track changes in specific household characteristics over the preceding twoyear period. The Phase II survey samples are discussed more completely in Columbia Research Center. (a)

(a) Columbia Research Center. 1985 (draft). 1985 Marketing Environment for BPA Conservation Activities: Phase I1. Prepared for Pacific Northwest Laboratory, Portland, Oregon. 


\subsection{SURVEY AND SAMPLE DESCRIPTION}

During the 1987 Phase III study, a survey specifically designed to continue the tracking effort initiated in the Phase II study was fielded. The tracking analysis of Phase III set out to test the hypothesis that household perceptions of energy conservation and affiliated institutions, energy conservation actions, and fuel switching had not changed during the study period. A second hypothesis was that the size and psychographic profile of market segments had not changed over the same period.

The 1987 tracking survey covered 503 households in the same, previousiy surveyed, geographic regions. The data (from each survey) presented in this report have been weighted to approximate population values in the BPA service region. Detailed tabular sample characteristics and applicable sample weights for each of the surveys are shown in Appendix $A$ and $B$, respectively.

The predominant population characteristics (after the 1987 sample group has been weighted) include $60 \%$ female, generally between the ages of 25 and 44 years $(52 \%)$. Almost $65 \%$ of the population has attended some college, considers itself part of a professional and clerical/sales/technical labor force $(58 \%)$, is a homeowner $(71 \%)$ and has resided in the current residence more than 5 years $(55 \%)$. Approximately $76 \%$ of the population lives in single family homes. Nearly $33 \%$ are two-occupant households, with three- and fouroccupant households each accounting for $19 \%$ of the population. Annual household income is above $\$ 30,000$ for $44 \%$ of the population, and between $\$ 16,000$ and $\$ 30,000$ for $33 \%$.

In tracking attitudes, perceptions and actions of a particular market, it is best to draw responses from similar samples across the study period. With the exception of education and income, the characteristics of those who responded to the 1987 survey are quite similar to those who responded to the 1983 and 1985 survey. The educational level of respondents in the 1987 survey is somewhat higher. For income, the percentage of the population earning between $\$ 16,000$ and $\$ 30,000$ has steadily declined (from $43 \%$ in 1983 to $33 \%$ in 1987), while those earning over $\$ 30,000$ has increased markedly (from $30 \%$ in 1983 to $44 \%$ in 1987). Assuming that these characteristics have 
changed in this manner for the population as a whole, it is not unrealistic to assume that similar groups were surveyed and that comparisons can be made across the study period.

\subsection{REPORT FORMAT}

Detailed analysis results are divided into six chapters and three appendices. Chapter 2.0 presents major conclusions for each of the following chapters. Chapter 3.0 highlights the importance of conservation as a major socioeconomic issue relative to other major issues. This chapter also identifies images that consumers have of energy conservation and affiliated institutions. Chapter 4.0 reviews the trends in adoption of energy conservation measures (ECMS) and the likelihood that householders in the survey area will install additional measures. Chapter 5.0 focuses on primary heating fuels and fuel switching. Chapter 6.0 discusses many of the topic areas noted above except that household survey responses are grouped by market segments and prospect groups. Appendix A presents the detailed contingency tables used to develop the conclusions and graphics presented throughout the report. Appendixes $B$ and $C$ discuss the sample weights and the statistical testing procedures and test results, respectively. 



\subsection{CONCLUSIONS}

This chapter begins with a discussion of major findings related to consumer perceptions of energy conservation. Next, energy conservation actions, both past and future, are reviewed. Conclusions related to primary heating fuels and fuel switching are then presented, and finally, market segments are addressed.

The analysis set out to test the hypothesis that household attitudes about energy conservation and affiliated institutions, energy conservation actions, and fuel switching had not changed during the study period. A second hypothesis was that the size and psychographic profile of market segments, as defined by past and intended conservation actions, had not changed.

\subsection{PERCEPTIONS OF ENERGY CONSERVATION AND AFFILIATED INSTITUTIONS}

Survey respondents were asked to rank their level of concern about major socioeconomic issues. According to the survey, major issues, ranked in descending order, are as follows: crime, cost of energy, inflation, energy conservation, unemployment, and energy use in the home. Concern about energy conservation declined between 1983 and 1985 but that decline reversed by almost an equal amount between 1985 and 1987. In summary, the level of concern for nonenergy issues has declined steadily, while level of concern for energy issues first declined between 1983 and 1985, then leveled out.

In all three surveys respondents indicated that they invest in energy conservation because they believe it saves them money, and enhances the comfort and value of their homes. Over the survey period, consumers' familiarity with the BPA and their local electric utility has increased, as has the number of "favorable impression" and "concern about the customer" ratings consumers gave when asked about these agencies. Local electric utilities are rated somewhat higher than the BPA as a believable source of information. 


\subsection{ENERGY CONSERVATION ACTIONS}

Building shell enhancements consist of weatherproofing, storm/thermal pane windows, basement/floor/crawlspace insulation, outside wall insulation, roof/attic insulation, and storm/insulated doors. Each of these shell enhancements had been widely adopted; roof/attic insulation was the most frequently adopted measure and storm/insulated doors were the least frequently adopted measure.

Use of weatherproofing, storm/thermal pane windows, and basement/floor/ crawlspace insulation increased over the study period. The use of outside wall and roof/attic insulation increased significantly between 1983 and 1985 then leveled off. Storm/insulated doors appear to have first dropped slightly, then increased to a level of nearly $70 \%$ of all homes.

The building equipment enhancement list includes heat pumps, auto/setback thermostats, woodstoves/furnace, water heater solar panels, and heat pump water heaters. According to Phase III survey responses, the heat pump has been installed in approximately $11 \%$ of the homes of the region; this is not significantly different from the levels of 1983 and 1985 . Water heater solar panels and heat pump water heaters were not addressed in the 1983 survey, but since 1985 they do not seem to have penetrated the energy conservation market to a large extent. Approximately two thirds of the homes in the region had woodstoves/furnaces and auto/setback thermostats. [The survey wording, however, raises questions about the validity of the results for woodstoves/furnace and auto/setback enhancements (see Section 4.1).]

Because most homes now have basic shell enhancements, the likelihood of further consumer investment has been declining for most measures. One exception is storm/insulated doors. After remaining constant from 1983 to 1985, consumers' interest in future investment for this enhancement increased in 1987.

Building equipment enhancements such as heat pumps, water heater solar panels, and heat pump water heaters are "likely to be installed in the next 2-3 years" in roughly one out of every ten homes, a response similar to the levels indicated in 1983 and 1985. Woodstoves/furnaces continue to be a measure likely to be installed in the near future. 


\subsection{PRIMARY HEATING FUELS AND FUEL SWITCHING}

Electricity increased its market share as a primary heating fuel during the course of the study period, reaching a level of nearly half of all homes by 1987 . Wood increased its share slightly between 1983 and 1985 but subsequently declined as the region's primary heating fuel to a current level of $22 \%$. Natural gas and oil maintained a fairly constant market share.

Approximately 275,000 households appear to have switched their primary heating fuel in the period between 1983 and 1985; approximately 135,000 households switched between 1985 and 1987. In the 1985-1987 period, electricity was dropped as the primary heating fuel about half of the time; natural gas was less likely to be the primary fuel dropped. This result contrasted with the 1983 to 1985 period when wood held much public favor and was less likely to be dropped.

Households that switched fuels most often adopted wood as their primary heating fuel, followed by electricity. In the early period, wood was adopted for nearly $60 \%$ of the fuel switches; however, it has since fallen to $46 \%$. The decline in wood was offset by increases in electricity, natural gas and oil as the "new primary fuel" chosen by survey respondents who had switched fuel.

\subsection{MARKET SEGMENTATION}

Energy conservation market segments can be established using information about respondents' past behavior and expressed intentions toward energy conservation measures (ECMs). The market segment specifically addressed here is the first-tier prospects. The first-tier prospects are defined as those consumers who are most likely to make investments in conservation and, therefore, are assumed to represent the group most likely to contribute to additional energy conservation in the region. First-tier prospects have installed at least two ECMs in the past and indicated they were likely to install at least one item in the next two or three years. The proportion of first-tier prospects dropped between 1983 and 1985 but has since then risen, possibly indicating a more conservation-conscious population exists today than during the earlier period. 
First-tier prospects were more likely to be females who had attended some college and consider themselves a part of the professional and clerical/sales/technical labor force. The proportion by sex and occupation has not changed dramatically over the study period and is quite similar to those of the general population. The education level of first-tier prospects, however, has increased over the study period and is roughly 10 percentage points higher than that of the general population.

The first-tier prospect is generally between the ages of 25 and 44 years, with 35- to 44-year-olds representing the largest portion of that group. First-tier prospects have typically resided in their current residence more than five years. Eight out of ten first-tier prospects live in single family homes. The proportion of this market segment within the single family dwelling group has dropped slightly, while that in the mobile home group increased between 1983 and 1987.

A third of the first tier is composed of two-occupant households. The shift over time has been from three- and four-occupant households to twooccupant households.

Annual household income is above $\$ 30,000$ for over half the group and between $\$ 16,000$ and $\$ 30,000$ for about one third of the group. The percentage of the group earning between $\$ 16,000$ and $\$ 30,000$ has steadily declined over the study period, while those earning over $\$ 30,000$ has increased markedly.

\subsubsection{Perceptions of Energy Conservation: First-Tier Prospects}

Almost without exception, first-tier prospects are more often very concerned about major socioeconomic issues than is the general population. Except for energy use in the home, energy and nonenergy issues are of high concern to over half of the first-tier group. While current levels of "very concerned" responses are somewhat lower than 1983 responses, they are fairly consistent with 1985 responses.

As was the case for the general population, first-tier prospects very often agree with the statement that people who invest in ECMs do so to save money. First-tier prospects also say they would invest in energy conservation because it enhances the comfort and value of the home. 


\subsubsection{Installed Energy Conservation Measures: First-Tier Prospects}

First-tier prospects have widely adopted building shell enhancements, Roof/attic insulation is the most frequently adopted measure and storm/insulated doors are the least frequently adopted measure. The current level of installations for each shell ECM is higher than at any other time in the study period.

According to survey responses the heat pump has been installed in approximately $13 \%$ of first-tier prospect homes; this percentage does not differ significantly from 1983 and 1985 levels. Water heater solar panels and heat pump water heaters have not been installed to a large extent by either the general population or by first-tier prospects.

About seven out of ten first-tier prospect homes had woodstoves/furnaces in 1983; closer to half of the group had woodstoves in 1985 and 1987. The auto/setback thermostat appears to have penetrated the ECM market increasingly over the study period.

\subsubsection{Intended Energy Conservation Measure Investment: First-Tier Prospects}

Because most first-tier prospects have basic shell enhancements, as discussed above, the likelihood of further investment has been declining for most measures. The likelihood that insulation for basement/floor/crawlspace, outside wall and roof attic will be purchased in the near future has consistently decreased; the current level averages about $30 \%$ of the first-tier homes. While the storm/insulated door dropped as a likely future measure from 1983 to 1985, in the 1987 survey it had increased by 11 percentage points for first-tier prospects.

Building equipment enhancements such as heat pumps, water heater solar panels, and heat pump water heaters are "likely to be installed in the next 2-3 years" in roughly two out of every ten first-tier prospects homes. This penetration level has remained fairly constant throughout the 1985 to 1987 period. Woodstoves/furnaces and auto/setback thermostats continue to be measures likely to be installed in the near future. 



\subsection{PERCEPTIONS OF ENERGY CONSERVATION AND AFFILIATED INSTITUTIONS}

This chapter highlights the importance of conservation as a major socioeconomic issue relative to other major issues. Consumers perceptions of energy conservation and affiliated institutions are also reviewed. A primary objective in presenting this information is to identify changes in the relative concern about issues and the perception of energy conservation so that marketing efforts can be structured around particular themes that seem to be important to consumers. Also, if a particular institution has achieved a high level of "goodwill" or believability in the public's eye, it may be appropriate for that institution to promote conservation programs.

Figures 3.1 through 3.4 display graphically the current perceptions and attitudes, as well as trends, on issues and energy conservation. Detailed tables containing the data used to create the figures can be found in Appendix A.

\subsection{ENERGY CONSERVATION AS A MAJOR SOCIOECONOMIC ISSUE}

To explore the relative importance of energy conservation as a major socioeconomic issue, specific issues were identified and surveyed over the study period: energy conservation, energy use in the home, cost of energy, crime, inflation, and employment. Survey respondents were to identify their level of concern for each issue, although only "very concerned" responses are shown in Figure 3.1. More specifically, the question was phrased as follows:

"Now I'm going to read you a short list of topics that some people are concerned about. Please tell me how you personally feel about. each of these topics - would you say you are very concerned, somewhat concerned, not very concerned, or not at all concerned about energy conservation?"

As was the case in each survey period, more people were very concerned about crime than any other single issue. In $198374 \%$ of the population was very concerned, $67 \%$ in 1985 , and $62 \%$ in 1987 . Cost of energy and inflation were the second and third most frequently cited issues. The number of people 
FIGURE 3.1. Issues Consumers Are "Very Concerned" About

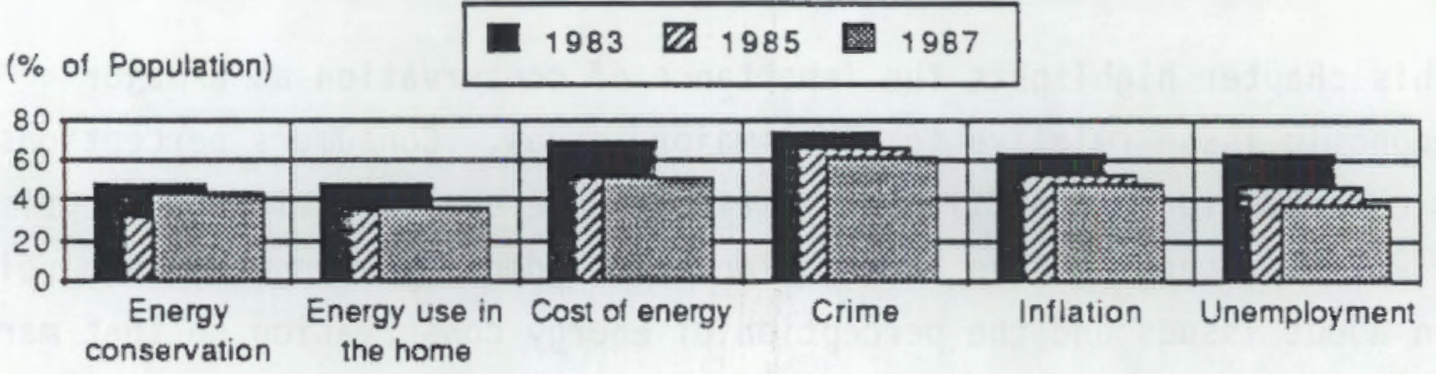

FIGURE 3.2. Energy Conservation Statements Consumers Agree With

(\% of Population)

\section{W 1985 娄 1987}

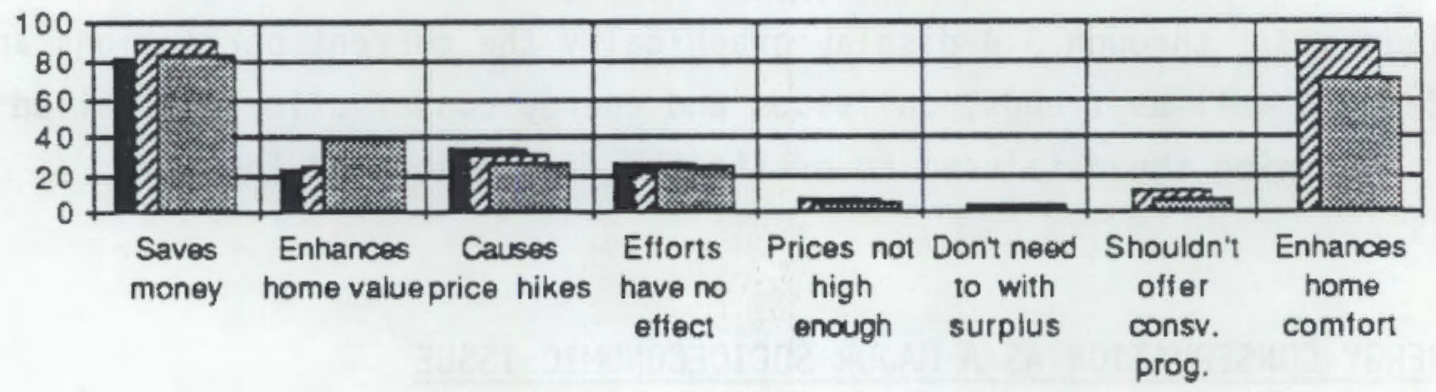

FIGURE 3.3. Perceptions of the Local Electric Utility

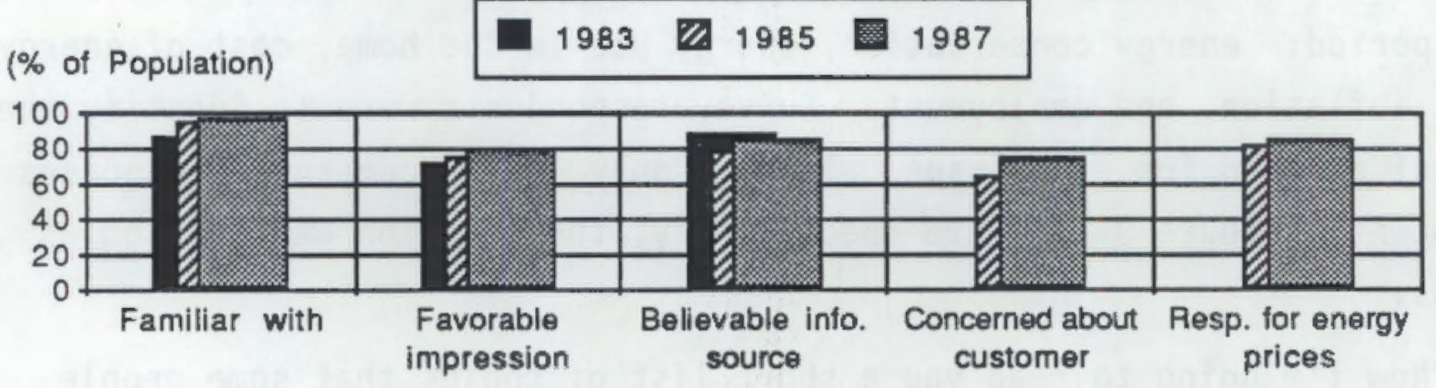

FIGURE 3.4. Perceptions of the Bonneville Power Administration

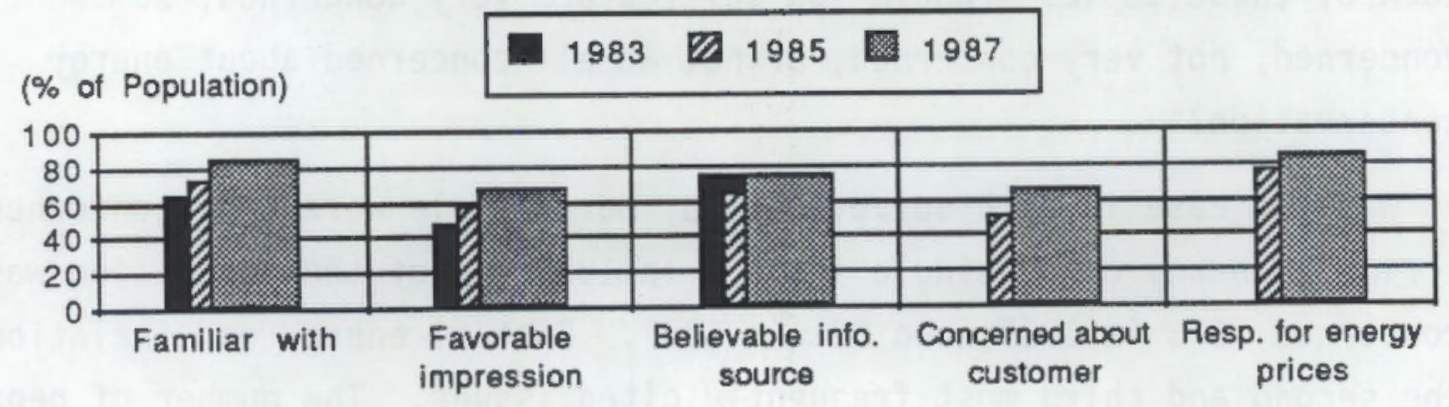


who were very concerned about unemployment declined relatively sharply over the study period. Those concerned about energy conservation declined between 1983 and 1985 but that decline reversed by almost an equal amount between 1985 and 1987.

If one assumes the level of importance is reflected by "very concerned" responses, each energy-related issue declined in importance from 1983 to 1985. They also appear to be less important than the non-energy issues. However, while the public continues to judge the non-energy issues as progressively less important, their judgment of the energy issues has at least stayed at the 1985 levels if not increased. Note that of the energy issues, energy conservation increased the most (by 11 percentage points).

\subsection{ENERGY CONSERVATION IMAGES}

Responses to attitude statements in the survey can be used to characterize respondents' perceptions of energy conservation. An attempt was made to provide an equal number of contextually positive and negative statements so as to cover a wide range of possible attitudes. The opening to the statements was posed in this manner: "I'm going to read a list of statements about how some people feel about various issues. With a response ranging from strongly disagree, disagree, neutral, agree, and strongly agree, please tell me how you feel about each of the following statements." The statements are shown below and are abbreviated in Figure 3.2.

Most people who conserve energy do so to save money.

I would only make conservation investments that would enhance the value of my home.

I would invest in ECMs because it increases the comfort of my home.

It's silly to conserve electricity because the electric utility just turns around and charges more for what you do use.

My conservation efforts won't have much effect one way or the other on the availability of electricity.

Electricity prices in the Northwest are not high enough to necessitate conservation activities. 
With the current power surplus in the Northwest there is no need conserve electricity.

Utilities should stop offering a variety of programs to encourage energy conservation.

A review of the figures shows that a large number of people still agree that conserving energy will save money and that energy conservation measures will increase the comfort of their home. While the number who agree is relatively high, it has declined in the last two years. Note that the number of the population who said they would make conservation investments that "would enhance the value of the home" has increased from $24 \%$ to $41 \%$. Based on these findings it may be appropriate to market conservation programs by promoting the concept of "conservation saves money" and "enhances the comfort of the home." The concept that energy conservation "enhances home value" is likely to become more and more attractive.

The statement that conservation induces price hikes, which is designed to identify negatives perceptions, lost some support between 1985 and 1987. According to survey results, the remaining attitudes continued to win little agreement among the population. Note that the last four statements shown in Figure 3.2 are applicable only to 1985 and 1987.

\subsection{PERCEPTIONS OF ENERGY INSTITUTIONS}

The remaining section in this chapter focuses on the population's perception of their local electric utility and the Bonneville Power Administration. When specifically addressing "familiarity with" questions, proportions cited are percentages of all respondents. All other proportions given are percentages of only those respondents who were familiar with the individual institutions.

Questions in the survey were typically worded as follows: "Please tell me how you feel about your electric utility in terms of their concern for the consumer? Would you say they are ... very concerned, concerned, neutral, not very concerned, or not at all concerned." Positive responses, in this case responses of "very concerned" and "concerned," are then included in the frequency count. Almost without exception, both institutions appear to have 
improved their image (shown in Figures 3.3 and 3.4). More specifically, the number of people familiar with the institutions has increased as has the "favorable impression" and "concern about the customer" rating. For example, in $198365 \%$ of the population was familiar with the BPA but by 1987 this level increased to $87 \%$. The number of favorable impressions of the BPA had increased by a similar percentage $(21 \%)$. Along with this, the perception that these institutions are responsible for energy prices has increased. Each institution's "believability as a source of information" rating has basically remained the same, at about $81 \%$ of the population for the local electric utility and $76 \%$ for the Bonneville Power Administration. 



\subsection{ENERGY CONSERVATION ACTIONS}

This chapter contains a discussion of trends in respondents' decisions to install ECMs and of the likelihood that they will install additional ECMs. Figures 4.1 through 4.4 present the data analysis results for this section. Again, more detailed results can be obtained from Appendix A.

\subsection{INSTALLED CONSERVATION MEASURES}

In each survey respondents were asked about the ECMs that were installed in their homes. Tabulations of specific ECMs were restricted to responses from owner-occupied homes. The specific measures addressed can be classified as either building shell or building equipment enhancements.

\subsubsection{Building Shell Enhancements}

Building shell enhancements consist of weatherproofing, storm/thermal pane windows, basement/floor/crawlspace insulation, outside wall insulation, roof/attic insulation, and storm/insulated doors. As demonstrated in Figure 4.1, each of the shell enhancements has been widely adopted. Roof/attic insulation was the most frequently adopted measure (95\%) and storm/insulated doors were the least frequently adopted measure $(71 \%)$.

The amount of weatherproofing, storm/thermal pane windows, and basement/floor/crawlspace insulation installed increased over the study period. Installation of outside wall and roof/attic insulation increased significantly between 1983 and 1985, then leveled off. Storm/insulated doors first dropped, then increased to its current level.

\subsubsection{Building Equipment Enhancements}

The building equipment enhancement list includes heat pumps, auto/setback thermostats, woodstoves/furnaces, water heater solar panels, and heat pump water heaters. The analysis of survey responses for these measures is shown in Figure 4.2. Over the survey period, heat pump installations have remained at approximately $11 \%$ of the homes surveyed. Water heater solar 
FIGURE 4.1. Installed Shell Enhancements

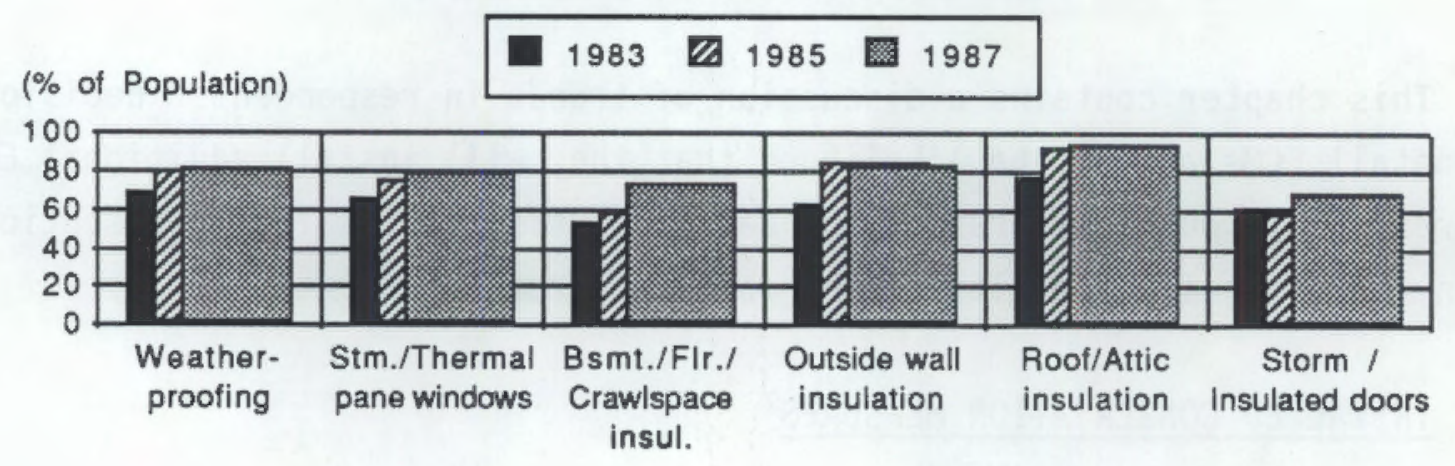

FIGURE 4.2. Instalied Equipment Enhancements

(\% of Population)

$$
1983 \% 1985 \text { 眯 } 1987
$$

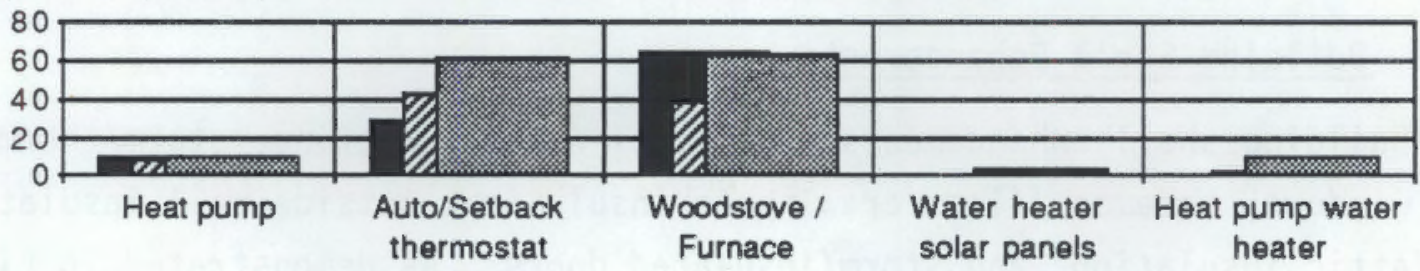

FIGURE 4.3. Intended Investment in Shell Enhancements

(\% of Population)

\section{3 】 1985 줍 1987}

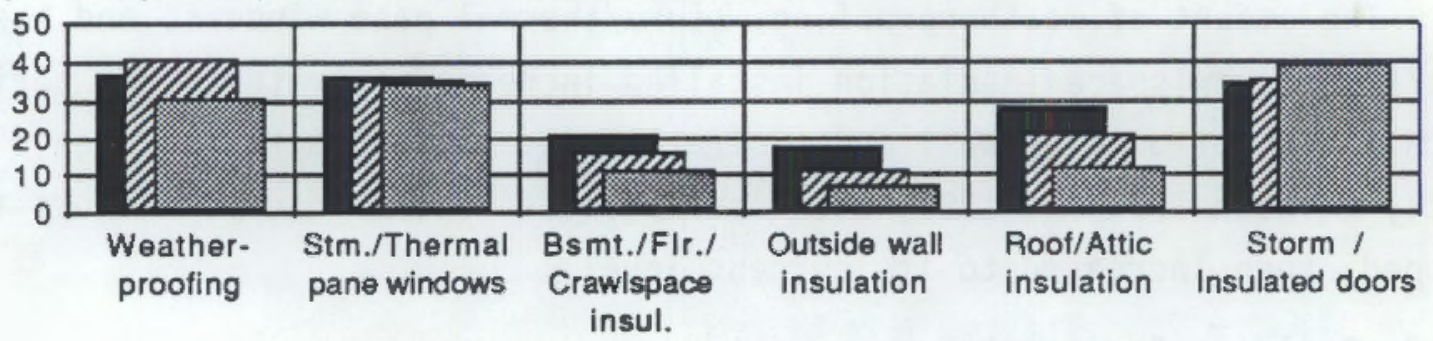

FIGURE 4.4. Intended Investment in Equipment Enhancements

(\% of Population)
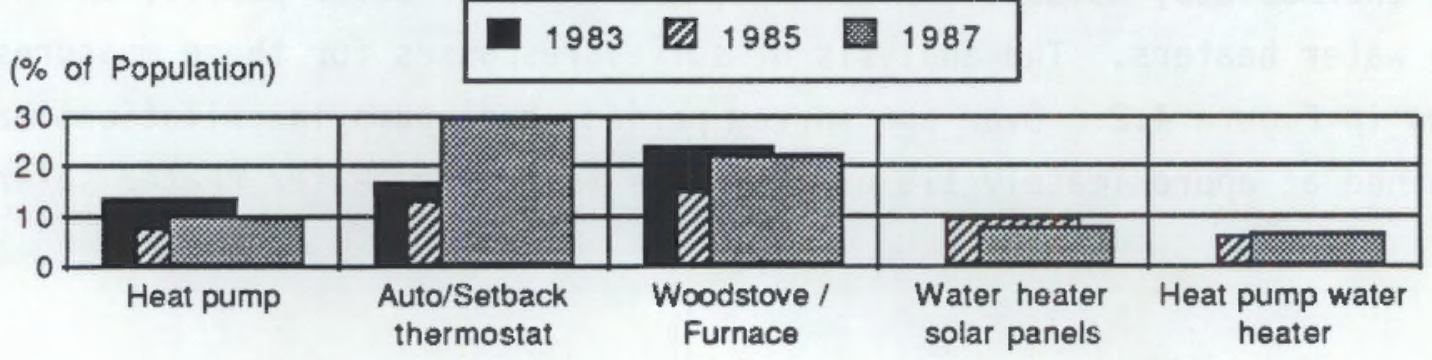
panels and heat pump water heaters were not addressed in the 1983 survey, but since 1985 they do not seem to have penetrated the energy conservation market to a large extent.

Woodstoves/furnaces appear in about 65\% of the homes during both 1983 and 1987 but in only $40 \%$ of the homes in 1985. This apparent inconsistency may have occurred because fireplace inserts were treated independently in the 1985 survey. That is, the 1983 and 1987 surveys did not specifically ask respondents about fireplace inserts while the 1985 survey did. In fact, respondents may have included fireplace inserts in their woodstove/furnace responses in 1983 and 1987, which would account for the higher percentage in that category for those years. When the 1985 fireplace inserts responses are added into the woodstove/furnace group the 1985 level increases to $59 \%$.

The most dramatic increase over the study period was in the number of auto/setback thermostats installed, rising from $29 \%$ in 1983 to $62 \%$ in 1987. A note of caution about this finding is warranted in that the survey questions were not consistent across each survey. More specifically, the 1983 question called this measure an "installed automatic or clock thermostat setback" while the later survey questions were worded "automatic or setback thermostat." The 1983 question could accurately be read as an "installed automatic setback or clock thermostat setback." It is likely that respondents perceived the 1985 and 1987 questions as either an "automatic thermostat or setback thermostat" with a automatic thermostat perceived as the typical wall unit found in most homes.

\subsection{INTENDED FUTURE CONSERVATION INVESTMENT}

Figures 4.3 and 4.4 present the responses to questions about the likelihood of installing specific measures in the home in the next two to three years. More specifically, respondents whose homes were not equipped with a specific ECM were asked a question similar to, "How likely is it that you will spend money to install weatherproofing within the next 2-3 years? Would you say it is very likely, somewhat likely, not very likely, or not at all likely?" Residents who already had a specific shell improvement installed were asked, "How likely is it that you will spend money to install 
more weatherproofing in your residence in the next 2-3 years." Respondents were given the same possible responses. Response frequencies were then calculated for "very likely" and "somewhat likely" responses. Again, the measures are divided into shell and equipment enhancement categories and are tabulated only for owner-occupied responses.

\subsubsection{Building Shell Enhancements}

Because most homes now have basic shell enhancements, as discussed above, the likelihood of further penetrating the market has been declining for most of the measures shown in Figure 4.3. From the population estimates, $35 \%$ are likely to add storm/thermal pane windows to their homes in the next two to three years; respondent intentions are very much like those indicated in 1983 and 1985. Additional weatherproofing will be added to $31 \%$, a drop of 6 percentage points from 1983 and 11 percentage points from 1985. Basement/ floor/crawlspace, outside wall and roof attic insulation have consistently decreased as measures likely to be added to the home in the near future. While storm/insulated doors remained constant as a likely future measure from 1983 to 1985, it increased by 5 percentage points by 1987 .

\subsubsection{Building Equipment Enhancements}

Building equipment enhancements such as heat pumps, water heater solar panels, and heat pump water heaters are "likely to be installed in the next 2-3 years" in roughly $10 \%$ of the homes. As shown in Figure 4.4 , this level has essentially remained unchanged throughout the study period.

Woodstoves/furnaces continue to be a measure likely to be installed in the near future. Although anticipated installations dropped $9 \%$ between 1983 and 1985, 1987 responses indicate a reversal in that trend, with a level now at $22 \%$. Again, because fireplace inserts were specifically addressed only in the 1985 survey, the respondents might currently have a fireplace insert and indicate that a woodstove will be added. Thus, there is some ambiguity surrounding tabulations for this ECM. 


\subsection{PRIMARY HEATING FUELS AND FUEL SWITCHING}

Chapter 5.0 reviews the fuel switching activities of households in the BPA service region. Although the 1983 survey did not contain questions specific to fuel switching, the 1985 questions prompted for changes in fuel use in the two preceding years. Therefore, the period covered in this chapter is 1983 through 1987 even though only two surveys have applicable data. These data are reflected in Figures 5.1 through 5.3.

\subsection{PRIMARY HEATING FUELS}

Figure 5.1 illustrates the trends in households' perception of their primary heating fuel, possibly an important distinction from the "actual" primary heating fuel used. Electricity has increased its market share as a primary heating fuel during the course of the study, reaching a level of $46 \%$ by 1987 . Wood increased its share slightly between 1983 and 1985 but subsequently declined as the primary heating fuel to a current level of $22 \%$. Natural gas and oil appear to have maintained a fairly constant market share of $20 \%$ and $10 \%$, respectively.

\subsection{PRIMARY HEATING FUELS DROPPED}

Approximately 275,000 households switched their primary heating fuel in the period between 1983 and 1985. Approximately 135,000 households switched between 1985 and 1987 . Electricity was the primary heating fuel that was dropped $47 \%$ of the time (as shown in Figure 5.2). 0 il and wood were both dropped about $19 \%$ of the time between 1985 and 1987, which reflects a change from the earlier period when oil was more likely to be the fuel dropped. Currently natural gas appears less likely to be the primary fuel dropped, which was not the case in the 1983 to 1985 period when wood held much public favor.

\subsection{PRIMARY HEATING FUELS ADOPTED}

Throughout the study period, the primary heating fuel most respondents switched to was wood, followed by electricity. Wood was adopted for nearly 
FIGURE 5.1. Primary Heating Fuels

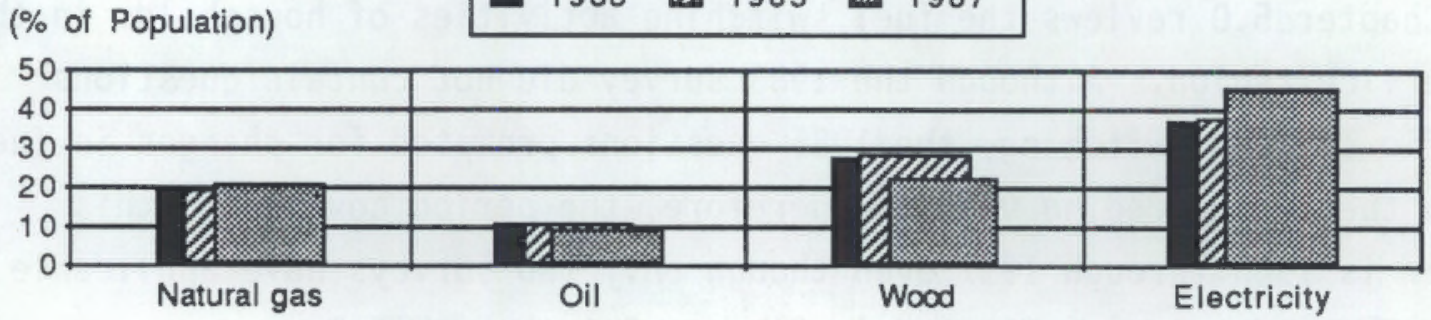

FIGURE 5.2. Primary Heating Fuels Dropped By Households that Switched

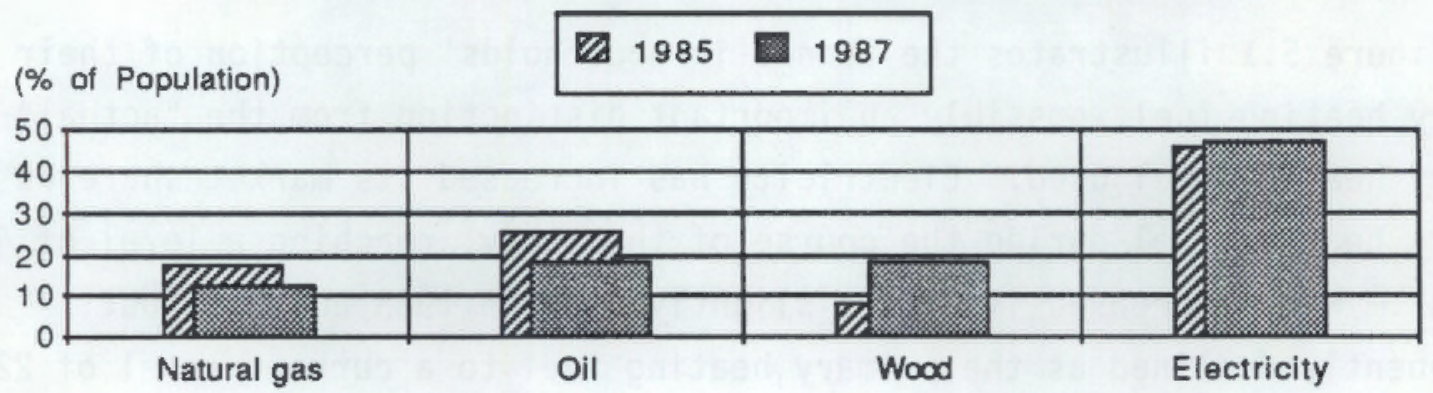

FIGURE 5.3. Primary Heating Fueis Adopted By Households that Switched

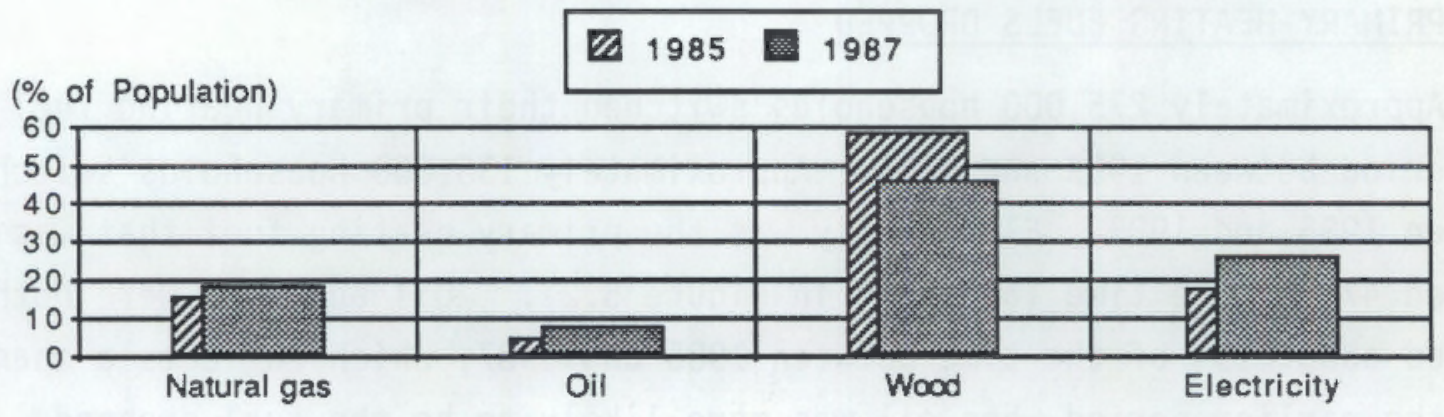


$60 \%$ of the fuel switches in the early period but has since fallen to $46 \%$. Electricity was selected $18 \%$ and $27 \%$ of the time for the 1985 and 1987 sample periods, respectively. Natural gas and oil have also picked up shares of the "new primary fuel" market were lost by wood.

Respondents seem to have two principal reasons for switching the primary heating fuel. Expense-related reasons for switching primary heating fuels are the first, although this category has fallen from $93 \%$ in 1985 to $70 \%$ in 1987. The second is the reliability/convenience reason, which increased from $7 \%$ to $30 \%$ from 1985 to 1987 . 



\subsection{MARKET SEGMENTATION}

This chapter defines and explains market segments represented by the sample and extends the definition to energy conservation "prospect" groups. In particular, these groups are labeled as first tier, second tier, and nonprospect groups. In the remainder of the chapter the perceptions and ECM actions of the prospect groups are examined.

\subsection{MARKET SEGMENTS AND PROSPECT GROUPS}

Energy conservation market segments can be established using information about the survey households' past behavior and expressed intentions toward ECMs. For this study, the analys is of market segments was based on responses only from owner-occupied households.

Past ECM investments can be categorized as "limited," "moderate," and "heavy." These categories and categories of "minimal"/"moderate"/"high" for intention to make future investment were used to create energy conservation prospect groups for the population represented by this sample (see Figures 6.1 and 6.2 ):

\begin{tabular}{|c|c|c|c|}
\hline Segment & Past Investment & Future Investment & Prospect Group \\
\hline A & Limited & Minimal & Nonprospect \\
\hline B & Moderate & Minimal & Nonprospect \\
\hline C & Heavy & Minimal & Second tier \\
\hline D & Limited & Moderate & Nonprospect \\
\hline E & Moderate & Moderate & Second tier \\
\hline $\mathbf{F}$ & Heavy & Moderate & First tier \\
\hline G & Limited & High & Second tier \\
\hline H & Moderate & High & First tier \\
\hline I & Heavy & High & First tier \\
\hline
\end{tabular}

The first-tier prospects are those consumers who are most likely to make investments in conservation. They have installed at least two ECMs in the past and indicated they are likely to install at least one item in the next 
As shown in Figure 6.2, the number of consumers in the nonprospect group has decreased by approximately 11 percentage points between 1985 and 1987 . Those consumers appear to have moved into the first- and second-tier groups since both these categories grew over the same time period. Whether the 9 percentage point rise in first-tier prospects came from the second-tier or from the nonprospect group is not clear, but it seems to indicate a more conservation-conscious population exists today than during 1983 and 1985.

This chapter will focus primarily on first-tier prospects because they are assumed to be the most likely to contribute to additional energy conservation in the region. That is not to say that the other groups could not be motivated to do the same, but it will likely require more effort and expense on the part of promoting or sponsoring institutions. Characteristics and trends of second-tier and nonprospect groups will be examined in relation to the first-tier findings.

Selected characteristics of the first-tier sample are shown in Figures 6.3 through 6.6. Characteristics not shown graphically but found in Appendix A include sex, education, occupation, and length of stay at the current residence.

The proportions by sex and occupation have not changed dramatically and are quite similar to those of the general population. Fifty-six percent of first-tier prospect are female and $52 \%$ consider themselves to be a part of the professional and clerical/sales/technical labor force. The education level of first-tier prospects has increased over the study period. Approximately $75 \%$ have attended some college, a proportion roughly 10 percentage points higher than that of the general population.

Sixty-three percent of first-tier prospects have resided in their current residence more than five years; this is 8 percentage points higher than the general population level.

Approximately $80 \%$ of the first-tier prospects live in single family homes. Thirty-three percent of first-tier prospects are two-occupant households with three- and four-occupant households each accounting for $17 \%$ and $28 \%$, respectively. Household size has shifted over time from three- and four-occupant households to two-occupant households; two-occupant households 
FIGURE 6.1. Residential Market Segmentations

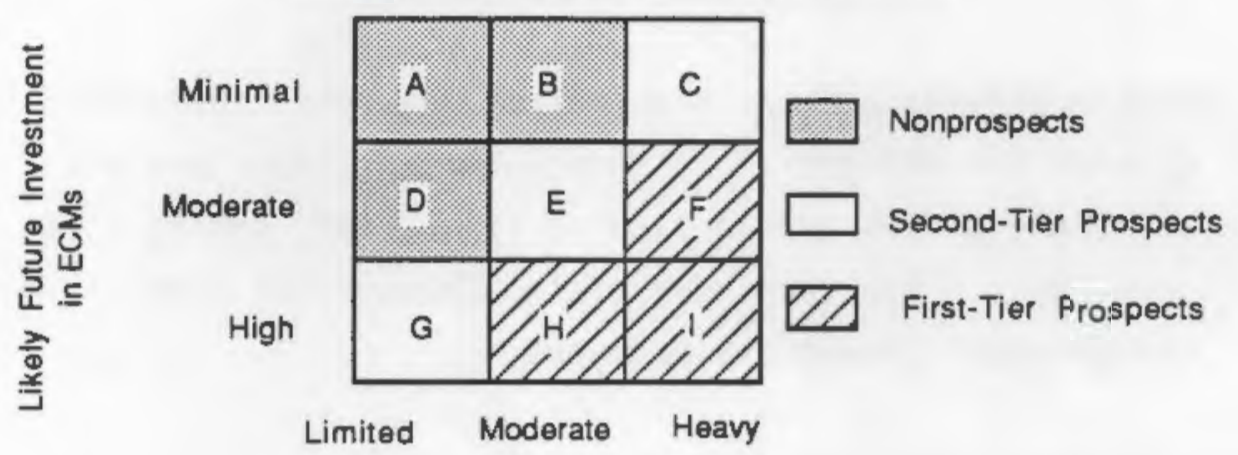

Number of Past Investments in ECMs

FIGURE 6.2. Prospect Group Households

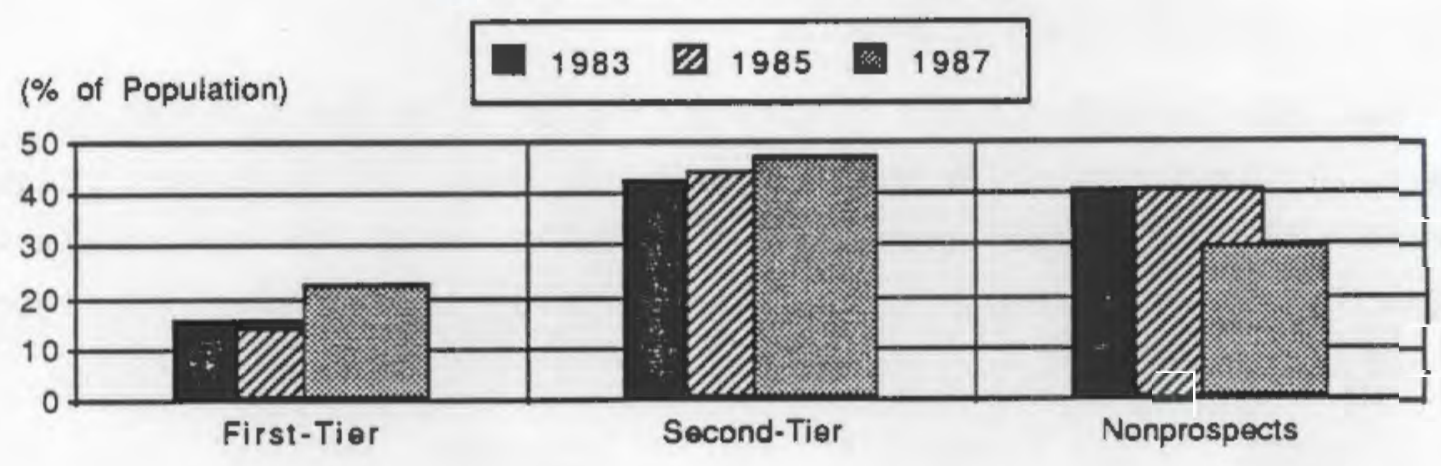

two or three years. However, those who invested "moderately" in the past and indicated the likelihood of future investment was "moderate" are excluded.

Second-tier prospects are those who have invested "heavily" but indicated that they are not likely to install any ECMs in the near future, those who have "moderate" past and "moderate" likelihood of future investment, or have had only "limited" investment in the past but are "highly" likely to invest in the future.

Nonprospects include those consumers who have a record of either "moderate" or "limited" past investment and a "minimal" or "moderate" likelihood of future investment. Those in the "moderate"/"moderate" group were assigned to the second tier, as noted above. 
FIGURE 6.3. Age: First-Tier Prospects

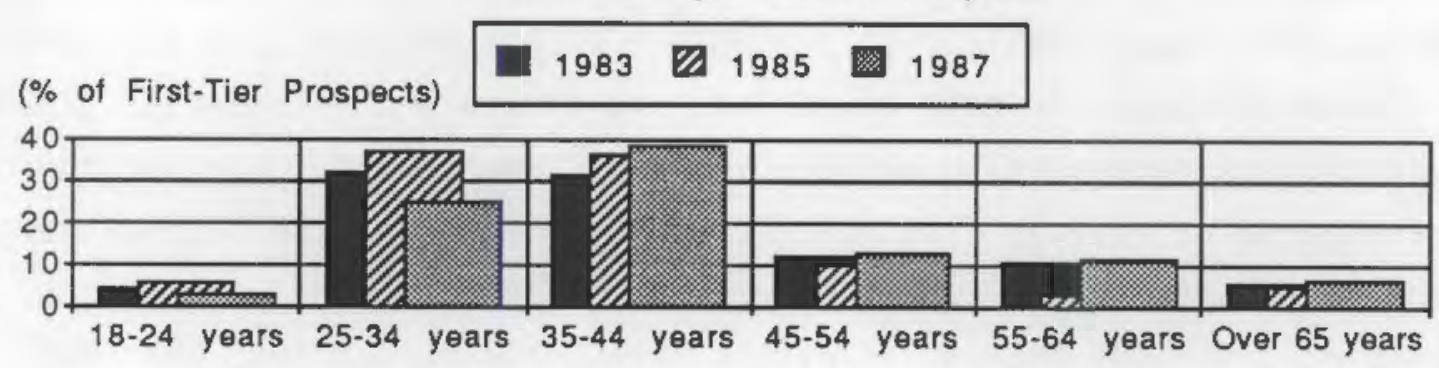

FIGURE 6.4. Annual Household income: First-Tier Prospects

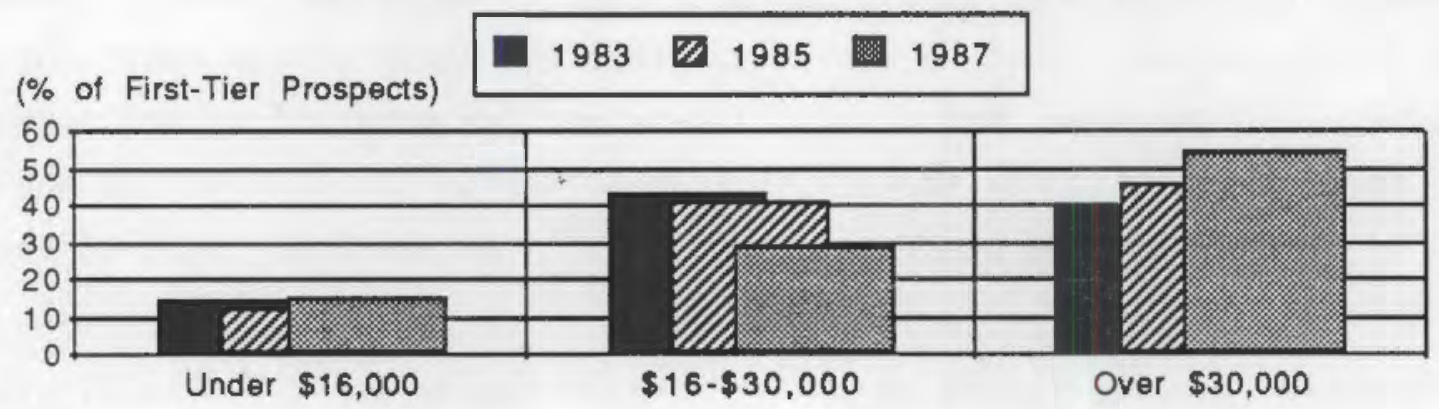

FIGURE 6.5. Type of Dwelling: First-Tier Prospects

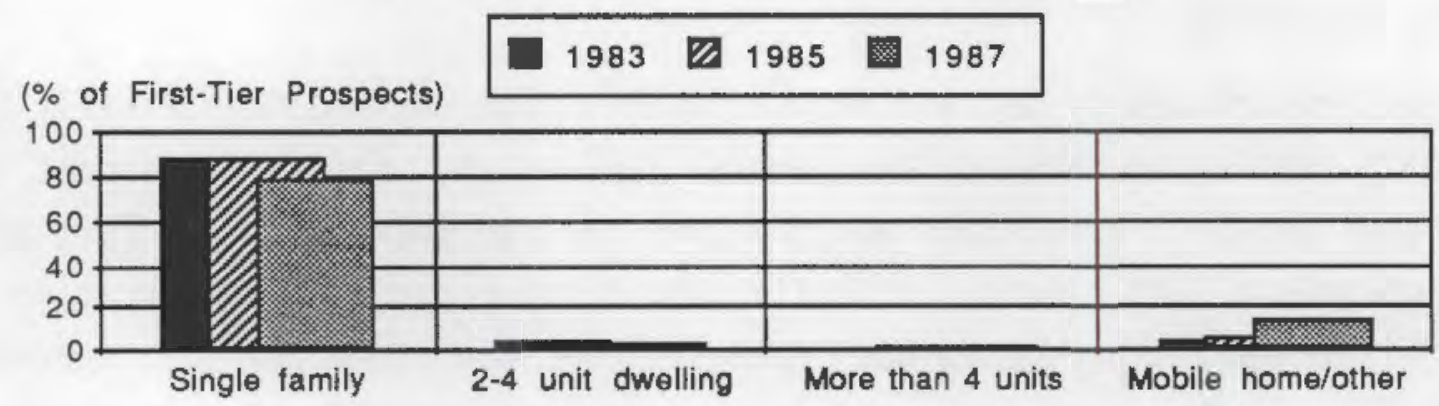

FIGURE 6.6. Size of Household: First-Tier Prospects

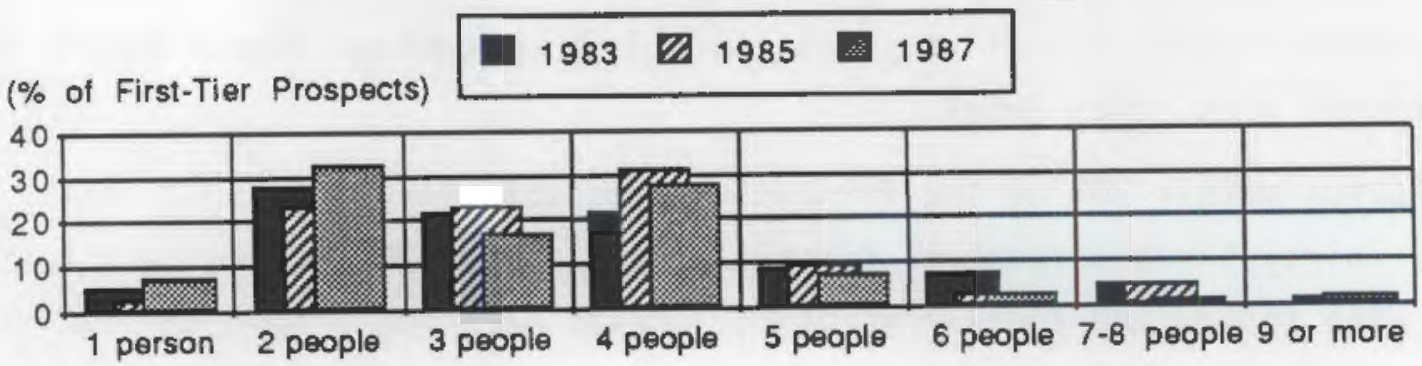


increased by 10 percentage points between 1985 and 1987 . The percentage of first-tier prospects in single-family dwellings has dropped slightly, while mobile home first-tier prospects have increased by 9 percentage points between 1983 and 1987.

The first-tier prospect is generally between the ages of 25 and 44 years $(64 \%)$, with $35-$ to $44-y e a r-0 l d s$ representing the largest portion of that figure $(61 \%)$. Annual household income is above $\$ 30,000$ for $55 \%$ of the group and between $\$ 16,000$ and $\$ 30,000$ for $29 \%$. The percentage of the group earning $\$ 16,000$ to $\$ 30,000$ has steadily declined (from $44 \%$ in 1983 to $29 \%$ in 1987), while those earning over $\$ 30,000$ have increased markedly (from $41 \%$ in 1983 to $55 \%$ in 1987).

\subsection{PERCEPTIONS OF ENERGY CONSERVATION: FIRST-TIER PROSPECT GROUP}

This section reviews both the perceptions of first-tier prospects toward energy conservation as a major socioeconomic issue and their attitudes toward energy conservation. Graphs that portray the results from segmenting this group are shown in Figures 6.7 and 6.8. As noted earlier, "very concerned" responses can be used as the basis for ranking the issues according to their current level of importance to respondents. (Refer to Section 3.1 for an example of the questions on issues.)

Almost without exception, first-tier prospects are more often very concerned about energy conservation, energy use in the home, cost of energy, crime, inflation, and unemployment than the general population. As shown in Figure 6.7 , the 1987 results indicate that roughly $50 \%$ to $60 \%$ of the firsttier group are very concerned about each issue except energy use in the home, which draws a very concerned response only $43 \%$ of the time. While current levels of "very concerned" responses are somewhat lower than 1983 responses, they are fairly consistent with 1985 responses. The primary exception to this is energy conservation, which declined sharply from 1983 to 1985 but then rose to nearly the 1983 level. Based on the results, it may be appropriate to assume that energy-related issues are of as much concern to first-tier prospects as are nonenergy-related issues. 
FIGURE 6.7. Issues First-Tier Prospects are "Very Concerned" About

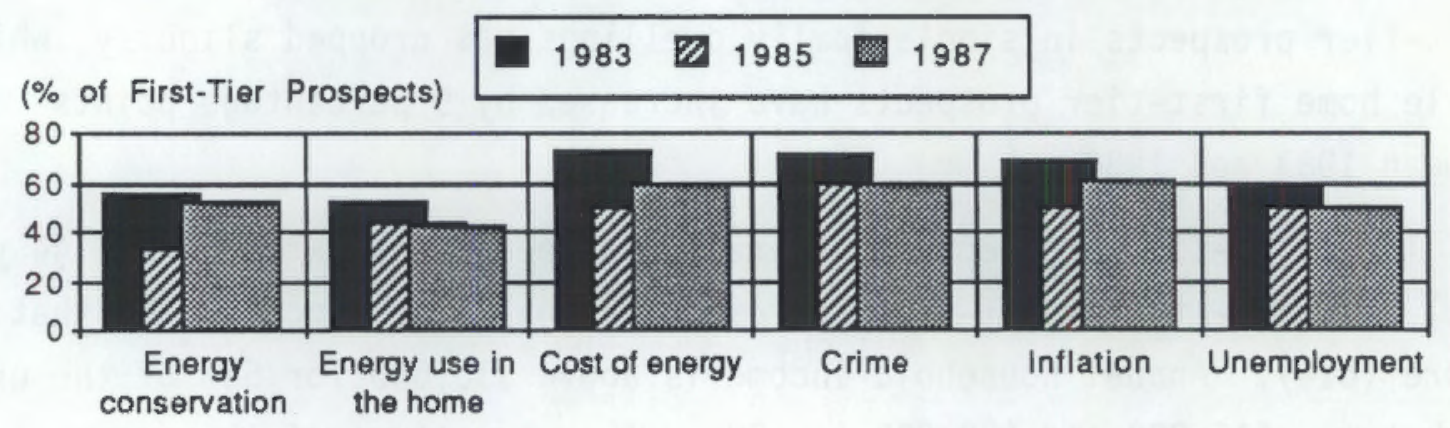

FIGURE 6.8. Energy Conservation Statements First-Tier Prospects Agree With

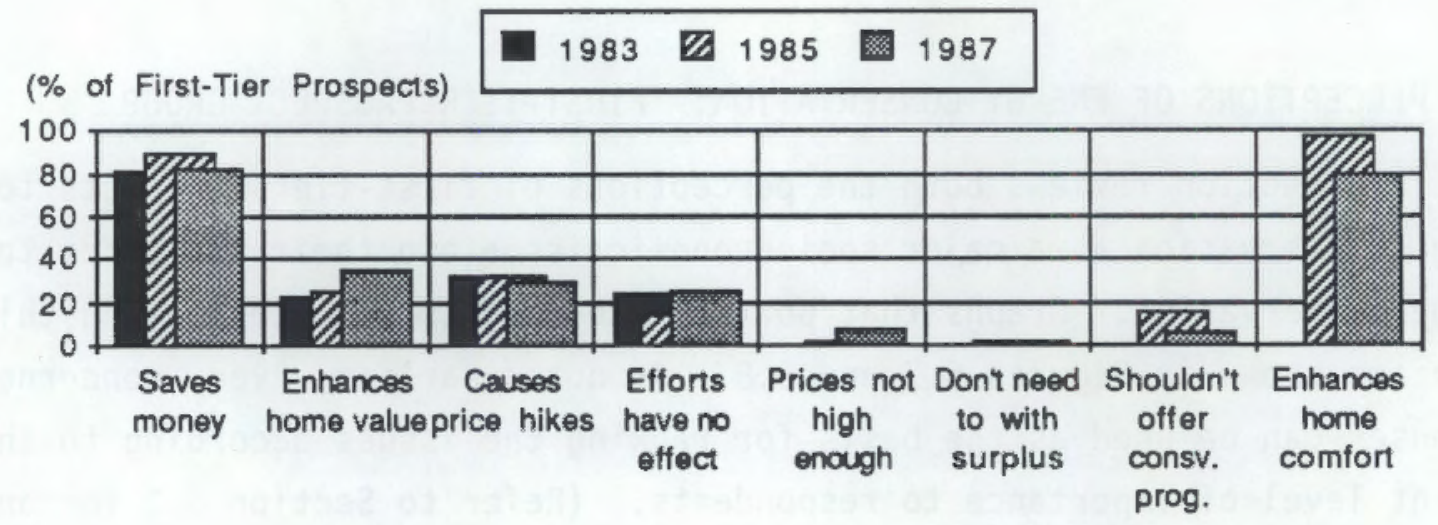

First-tier attitudes toward energy conservation are shown in Figure 6.8. (Refer to Section 3.2 for a breakdown of the statements and responses used.) As was the case for the general population, first-tier prospects very often agree with the statement that people invest in ECMs to save money and that they invest in energy conservation because it enhances the comfort of the home. Compared with the general population, $81 \%$ of whom agreed with the latter statement, first-tier agreement is lower by about $10 \%$. However, the belief in 1987 that ECMs enhance home comfort is down almost 20\% from levels recorded for 1985.

As illustrated, the remaining statements did not illicite significantly high nor variable levels of agreement over the study period. Thus, important marketing program themes may include: "energy conservation saves money, and enhances the comfort and value of the home." 


\subsection{INSTALLED ENERGY CONSERVATION MEASURES: FIRST-TIER PROSPECT GROUP}

The results discussed in this section are for the first-tier prospect group rather than the general population. Figures 6.9 through 6.12 show the installed building shell and building equipment enhancements for the firsttier group. Results were calculated from responses from owner-occupied homes only. Refer to the earlier section dealing with energy conservation actions for an example of the wording of questions presented to respondents. Again, more detailed results may be obtained from the tables found in Appendix A.

To re-emphasize, the specific measures addressed can be classified as building shell and building equipment enhancements. Building shell enhancements are weatherproofing, storm/thermal pane windows, basement/floor/crawlspace insulation, outside wall insulation, roof/attic insulation, and storm/insulated doors. Building equipment enhancements include heat pumps, auto/setback thermostats, woodstoves/furnaces, water heater solar panels, and heat pump water heaters.

\subsubsection{Installed Building Shell Enhancements: First-Tier Prospects}

As demonstrated in Figure 6.9, each of the shell enhancements has been widely adopted by first-tier prospects. Roof/attic insulation was the most frequently adopted ECM (96\%) and storm/insulated doors the least frequently adopted ECM $(77 \%)$. Each of the shell ECMs had increased to a level higher than at any other time in the study period. Storm/insulated doors and basement/floor/crawlspace insulation appear to have first dropped slightly between 1983 and 1985, then increased to their current level.

\subsubsection{Installed Building Equipment Enhancements: First-Tier Prospects}

According to survey responses, the heat pump has been installed in approximately $13 \%$ of first-tier prospect homes; this percentage is not significantly different from 1983 and 1985 levels. Water heater solar panels and heat pump water heaters do not seem to have penetrated the energy conservation market to a large extent with either the general population or first-tier prospects.

Woodstoves/furnaces appeared in the homes of about $71 \%$ of this market segment during 1983 , declined to $46 \%$ in 1985 , and rose to $61 \%$ in 1987 . 
FIGURE 6.9. Installed Shell Enhancements: First-Tier Prospects

(\% of First-Tier Prospects)

\section{3 『 1985 图 1987}

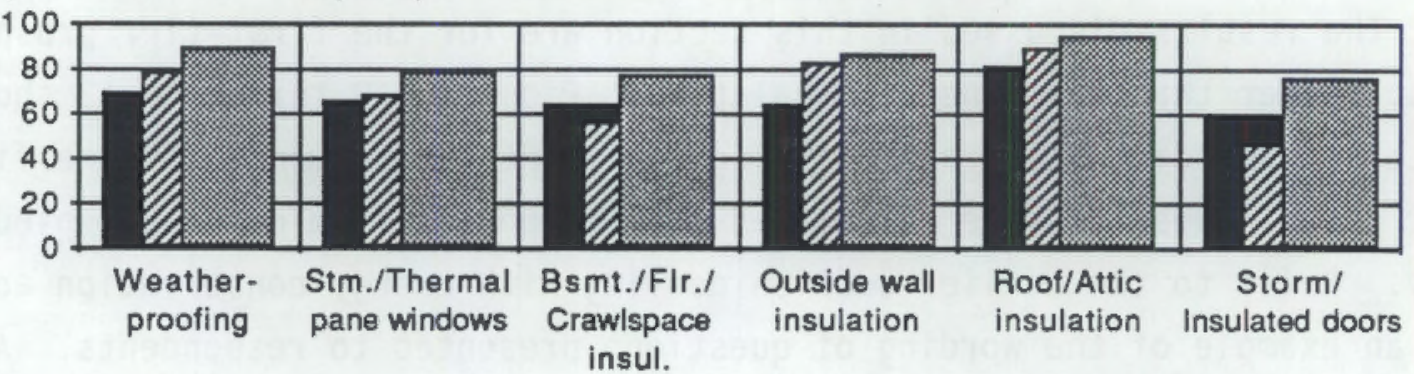

FIGURE 6.10. Installed Equipment Enhancements: First-Tier Prospects

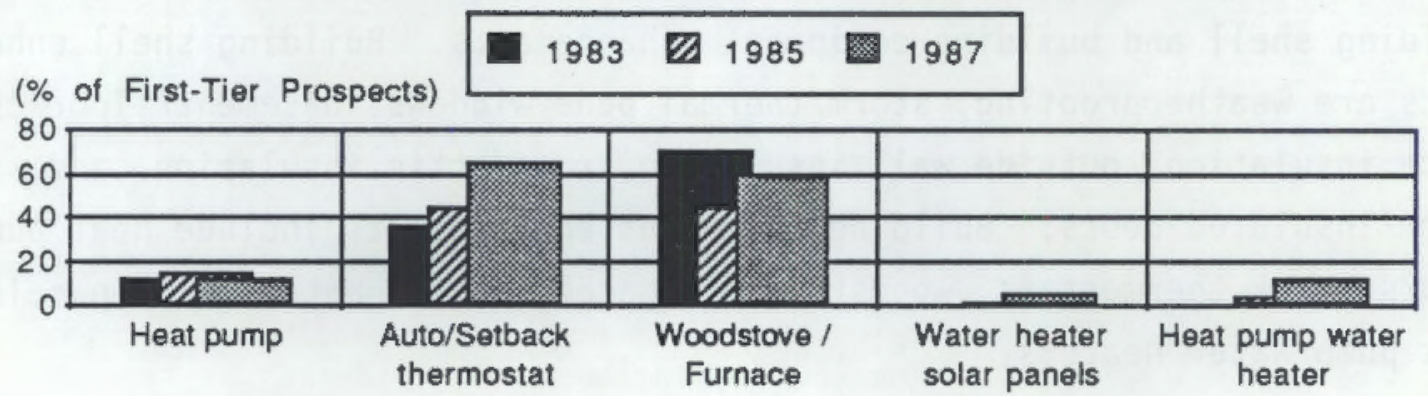

FIGURE 6.11. Intended Investment in Shell Enhancements: First-Tier Prospects

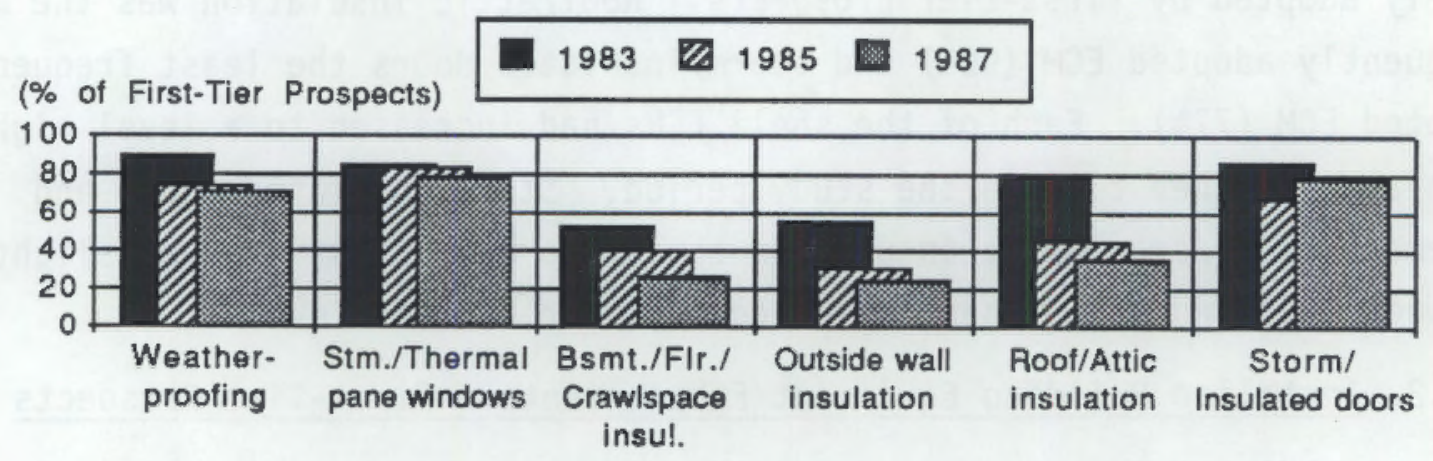

FIGURE 6.12. Intended Investment in Equipment Enhancements: First-Tier Prospects

(\% of First-Tier Prospects)

D 1983 W 1985 国 1987

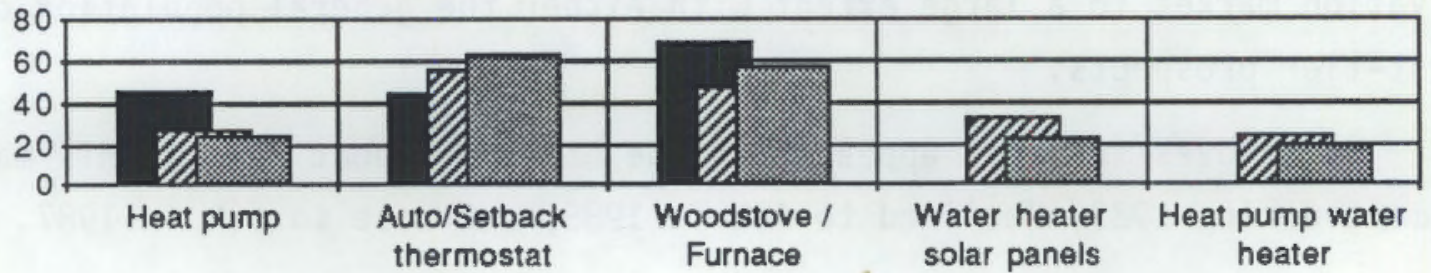


Recall that the manner in which the surveys dealt with woodstoves/furnaces versus fireplaces/inserts was inconsistent.

Again the auto/setback thermostat appears to have penetrated the market increasingly over the study period, rising from $37 \%$ in 1983 to $66 \%$ in 1987. In interpreting Figure 6.10 , the reader should bear in mind that different wording in the 1983 question on automatic setbacks may have influenced the results.

\subsection{INTENDED ENERGY CONSERVATION MEASURE INVESTMENT: FIRST-TIER PROSPECTS}

Figures 6.11 and 6.12 present the first-tier responses to questions about the likelihood, or intention, of installing specific ECMs in the home in the next two to three years. Again, the measures are divided into shell and equipment enhancement categories.

\subsubsection{Intended Building Shell Enhancements: First-Tier Prospects}

Because most first-tier prospects have basic shell enhancements, the likelihood that they will invest further has been declining for most of the measures shown in Figure 6.11. Recall that respondents were asked about the likelihood of adding additional insulation or weatherproofing if they already indicated they had some. About $81 \%$ of first-tier prospects are 1 ikely to add storm/thermal pane windows to their homes in the next two to three years, a result very much like the 1983 and 1985 results. Seventy-two percent of the first-tier group would add weatherproofing, a drop of $19 \%$ from 1983 and $4 \%$ from 1985. Basement/floor/crawlspace, outside wall and roof attic insulation have consistently decreased as measures likely to be added in the near future; the current level averages about $30 \%$ of the first-tier homes. While storm/insulated doors generally dropped as a likely future measure from 1983 to 1985 , it has increased by $11 \%$ for first-tier prospects.

\subsubsection{Intended Building Equipment Enhancements: First-Tier Prospects}

Building equipment enhancements such as heat pumps, water heater solar panels, and heat pump water heaters are "likely to be installed in the next 
2-3 years" in roughly $22 \%$ of the first-tier homes. As shown in Figure 6.12 , this penetration level has remained fairly constant throughout the 1985 to 1987 period.

Woodstoves/furnaces continue to be a measure likely to be installed in the near future. Although there was a 21 percentage point drop in anticipated installations between 1983 and 1985, 1987 responses have reversed that decline to a current level of $58 \%$. Because fireplaces were specifically addressed in the 1985 survey only, some ambiguity exists as to likely future installation of this measure. That is, fireplace inserts may in fact already exist in a home, but since the respondents were not specifically asked about them, they could have indicated they would add a woodstove/furnace to their residence.

More than any other single measure, the auto/setback thermostat has increased as a measure likely to be added in the near future. Sixty-three percent of first-tier respondents indicated a likelihood that they would install this ECM.

\subsection{OTHER PROSPECT GROUPS}

As shown earlier, the number of consumers in the nonprospect group has decreased by approximately 11 percentage points between 1985 and 1987 . Those consumers appear to have moved into the first- and second-tier groups, since both these categories grew over the same time period. Although the population of any particular group may have changed, attitudinal and behavioral trends may be similar. The following discussion will focus on characteristics of the second-tier and nonprospect groups and on the trends for these groups when they deviate from those of the first-tier group. For discussion purposes, only changes in excess of five percentage points will constitute a shift or change in a trend.

Recall that second-tier prospects are those who have invested "heavily" but indicated that they are not likely to install any ECMs in the near future, those who have "moderate" past and "moderate" likelihood of future investment, or have had only "limited" investment in the past but are "highly" likely to invest in the future. Nonprospects include those 
consumers who have a record of either "moderate" or "limited" past investment and a "minimal" or "moderate" likelihood of future investment.

\subsubsection{Population Characteristics}

Each of the prosect groups exhibits slightly different population characteristics. Between 1983 and 1987 the percentage of males representing the second-tier group first declines then increases. For the nonprospects, the number of females consistently increases and is higher for this group than for either of the others. The percentage of second-tier prospects in the occupational categories of professionals and crafts/foreman increase while "other employed" numbers decrease. Trends in other categories of employment are similar to the first-tier group. Nonprospect occupations tend to be something other than "professional," and the reported percentages exhibit an increase in the clerical/sales/technical fields while "other employed" declines as it did with first- and second-tier prospects.

The percentage of second-tier prospects in the 35 through 54 age category tends to increase over the study period. The number of nonprospects between the ages of 25 through 44 declines, while there is a simultaneous increase in the 55 and older category. Also, the second-tier group appears to be, on average, older than the first-tier group, and the nonprospects are more senior than either of these.

In terms of education, the second-tier group appears to become more educated as time goes on, while nonprospects have not changed their level of education significantly over the study period. Similar to age, as one moves from the first-tier to second-tier to nonprospect groups, the percentage of the population with "some college or more" decreases.

The trends in income and type of dwelling are basically the same for each prospect group. Note however, that the nonprospect group has higher proportions of lower income members than do the first- or second-tier group. Except for nonprospects, the household size is also fairly consistent across each prospect group and the study period. The one exception is that nonprospects appear to be more likely to be one- to two-member households while the other groups have two to four household members. 
The last population characteristic addressed is length of stay at the current residence. Second-tier prospects seem to be moving toward shorter lengths of stay at the residence, although a high percentage still have 5 years or more of residency. Nonprospects, on the other hand, seem to be more likely to have resided in the dwelling for a longer period of time, a trend that increases as time goes on.

\subsubsection{Perceptions of Energy Conservation}

This section reviews both perceptions toward energy conservation as a major socioeconomic issue and attitudes toward energy conservation. As noted earlier, "very concerned" responses are used as the basis for ranking the issues according to their current level of importance to respondents. (Refer to Section 3.1 and 3.2 for an example of the questions on issues and attitudes, respectively.)

The second-tier and nonprospect groups appear to be more concerned about non-energy-related issues than energy issues. Note, however, that the difference in proportions is not dramatic. Of all the issues, crime, inflation, and cost of energy consistently are the top three issues of concern throughout the study period. For the second-tier group all issues have become of less concern over the study period. However, nonprospects have renewed their concern about energy conservation and cost of energy after a decline during the 1983 to 1985 period.

Second-tier and nonprospect group responses to energy conservation statements do not deviate significantly from those of the first-tier group. That is, all prospects believe that energy conservation saves money and enhances home value and comfort. The percentage of those who believe this has declined over the study period, however.

\subsubsection{Installed and Intend-to-Install Energy Conservation Measures}

Respondents are categorized into prospect groups according to their "installed" and "intend-to-install" responses. These groupings for secondtier and nonprospect groups are shown in Figures 6.13 through 6.16 and Figures 6.17 through 6.20 , respectively. The fewer the number of installed measures and the less the intention to install ECMs, the more likely a 
FIGURE 6.13. Instalied Shell Enhancements: Second-Tier Prospects

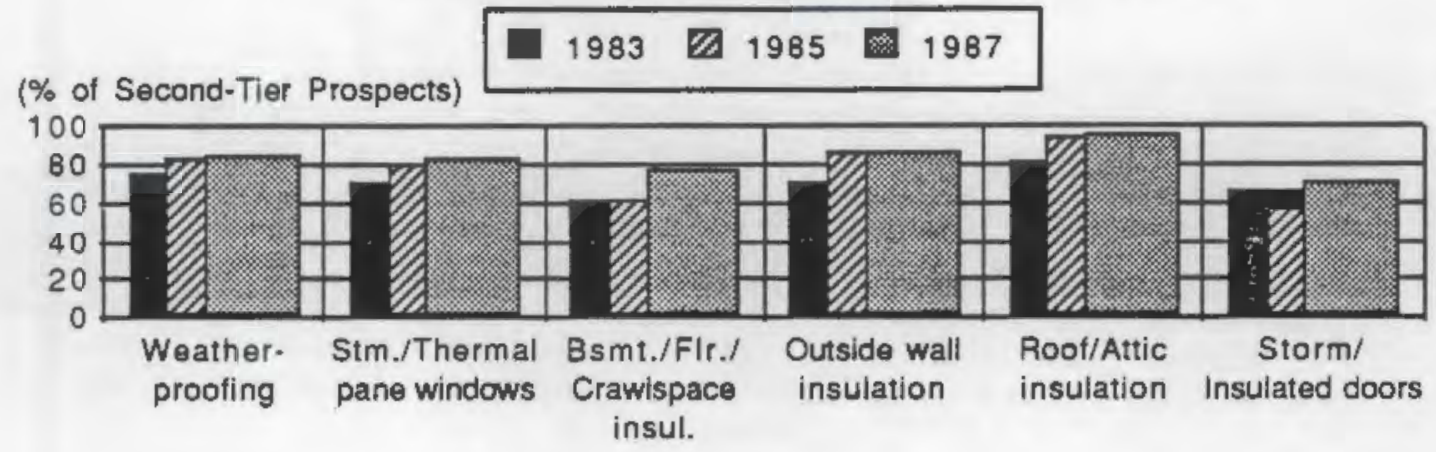

FIGURE 6.14. Installed Equipment Enhancements: Second-Tier Prospects

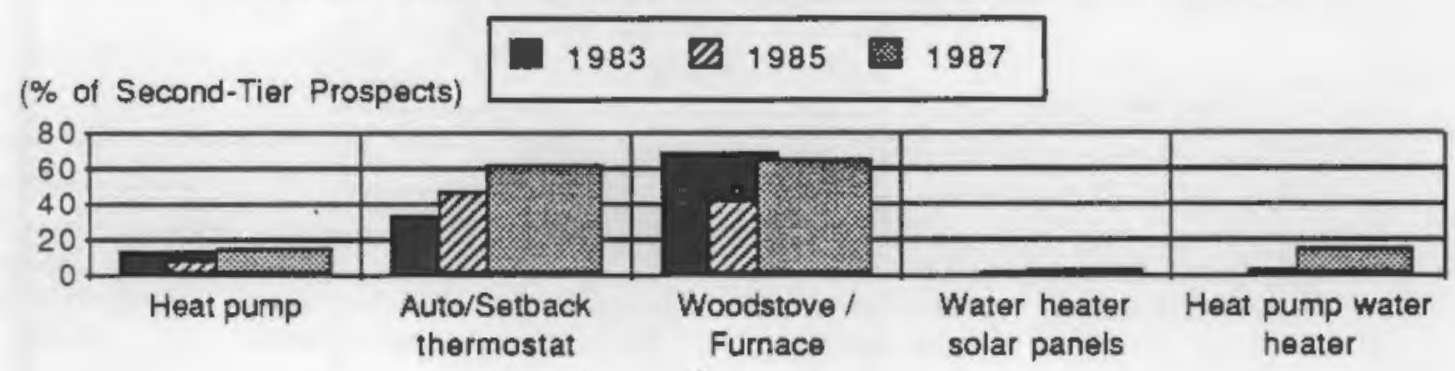

FIGURE 6.15. intended Investment in Shell Enhancements: Second-Tier Prospects

(\% of Second-Tier Prospects)

$$
1983 \text { W } 1985 \text { ه } 1987
$$

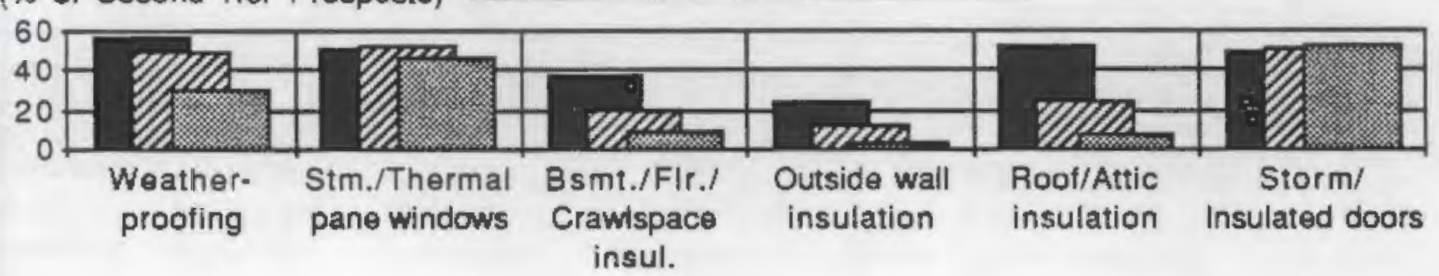

FIGURE 6.16. Intended Investment in Equipment Enhancements: Second-Tier Prospects

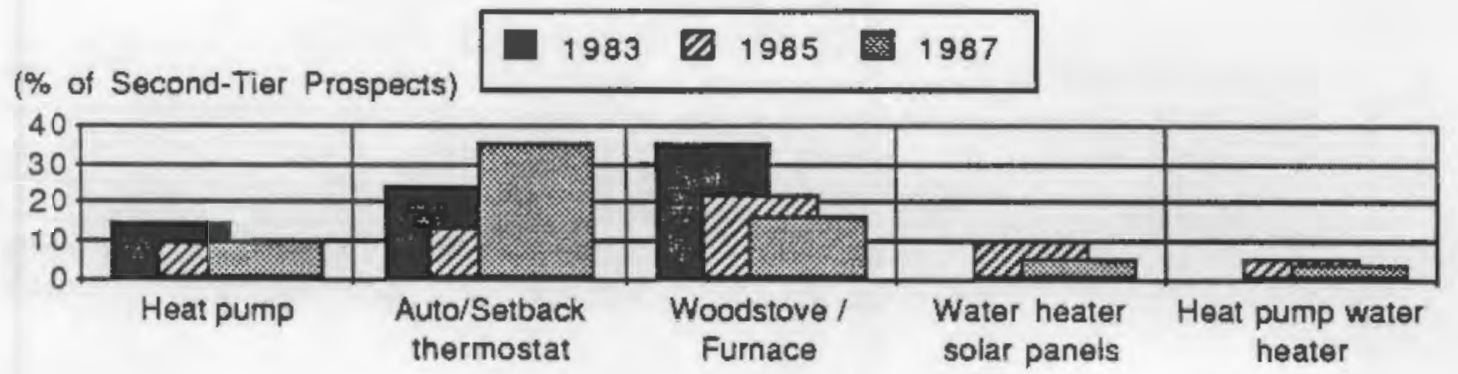


FIGURE 6.17. Installed Shell Enhancements: Nonprospects

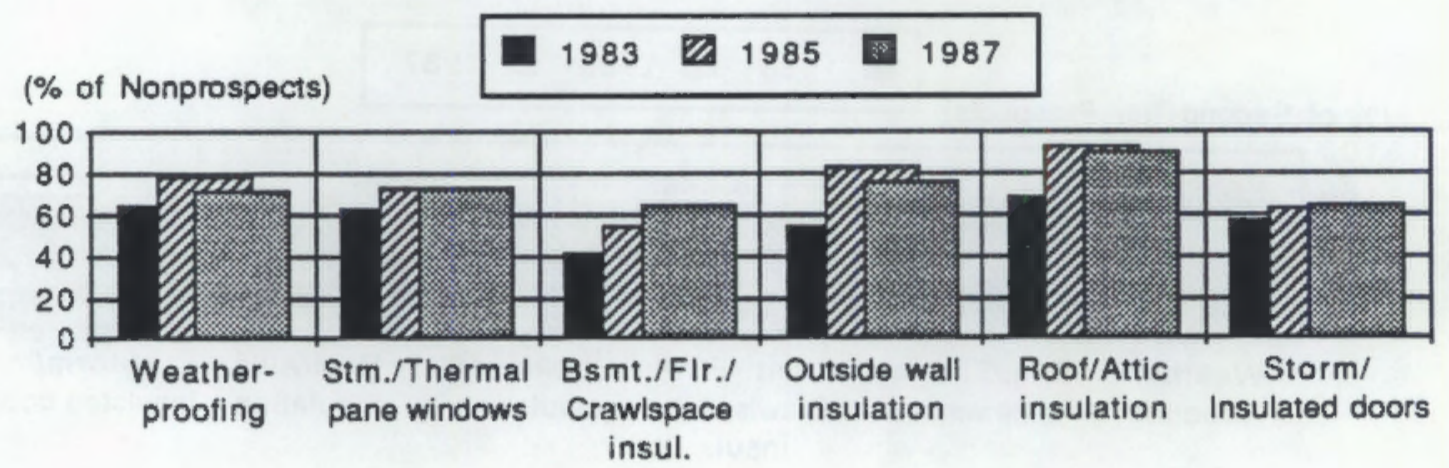

FIGURE 6.18. Installed Equipment Enhancements: Nonprospects

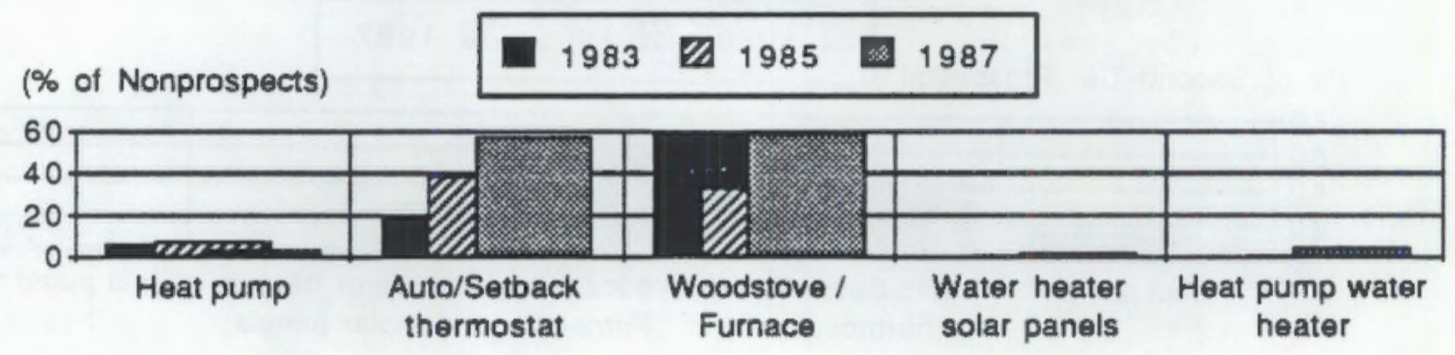

FIGURE 6.19. Intended Investment in Shell Enhancements: Nonprospects

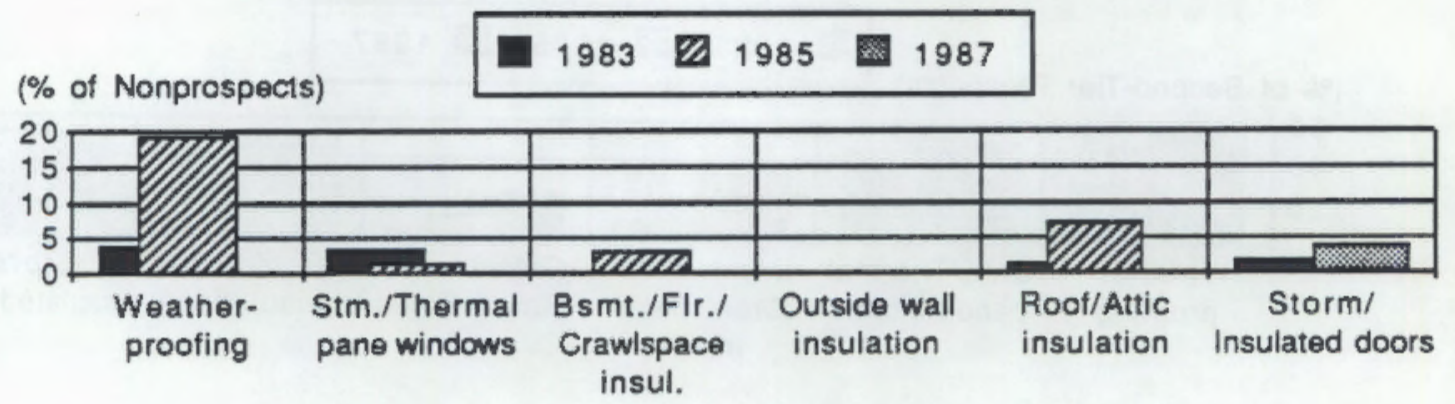

FIGURE 6.20. Intended Investment in Equipment Enhancements: Nonprospects

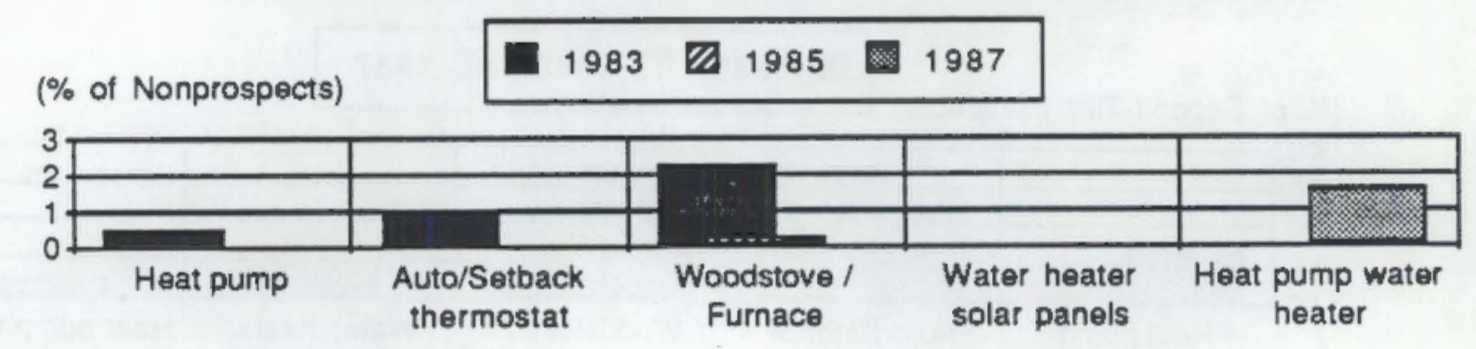


respondent will fall into the nonprospect group. Therefore, reported percentages will drop consistently when moving from the first-tier prospect results to second-tier to nonprospects. Most of the discussion surrounding the comparison of groups will be directed at what has changed during the course of the study period and not on actual percentage numbers.

Without exception, each of the building shell enhancements has been widely adopted by each of the prospect groups. Roof/attic insulation was the most frequently adopted ECM and storm/insulated doors the least frequently adopted ECM. With but a few exceptions, shell ECMs have continued to penetrate the market for each prospect group during the study period. The exceptions are that the nonprospect group installed less weatherproofing and outside wall insulation between 1985 and 1987. Note that the decline is only slight; thus, it may be appropriate to attribute it to sample error.

Regarding the likelihood of installing new or additional shell conservation measures, second-tier prospect trends are nearly identical to those of the first-tier group. Again, storm/insulated doors appear to be the only measure indicated to increase as a future home enhancement from 1985 to 1987. Non-prospect group results exhibit essentially no likelihood of installing shell ECMs.

Turning to building equipment enhancements, recall that the manner in which the surveys dealt with woodstoves/furnaces versus fireplaces/inserts was inconsistent and that the wording in the 1983 question on automatic setbacks may have influenced the results for this particular equipment enhancement. The number of second-tier or nonprospects who have installed building equipment is not significantly different from the first-tier group. Automatic/setback thermostats and woodstoves have penetrated the market increasingly between 1983 and 1985, while other equipment has not been widely installed. Regarding future equipment enhancements, one possible exception to the first-tier trend for the woodstove/insert exists: secondtier prospects indicate they are not likely to be adopting this ECM. Again, nonprospects indicate none of the equipment measures are likely to be adopted in the near future. 

APPENDIX A

CONTINGENCY TABLES FOR 1983, 1985, AND 1987 SURVEY RESULTS 
APPENDIX A

CONTINGENCY TABLES FOR 1983, 1985, AND 1987 SURVEY RESULTS

This appendix provides the data used to create the figures and arrive at the conclusions presented in the report. To facilitate locating data of interest, the appendix is arranged similarly to the report. Refer to Appendix $B$ for a review of statistical tests performed on the data.

\section{A.1 SUPPORTING DATA FOR CHAPTER 1.0}

TABLE A.1. Sex (\% of population)

Male

Fernale

\begin{tabular}{ccc}
1983 & 1985 & 1987 \\
\hline 46 & 38 & 41 \\
54 & 62 & 59
\end{tabular}

TABLE A.2. Age ( $\%$ of population)

18-24 years

25-34 years

$35-44$ years

$45-54$ years

$55-64$ years

Over 65 years

\begin{tabular}{ccc}
1983 & 1985 & 1987 \\
\hline 8 & 9 & 8 \\
28 & 25 & 25 \\
24 & 24 & 27 \\
13 & 15 & 16 \\
14 & 13 & 13 \\
13 & 14 & 12
\end{tabular}

TABLE A.3. Education (\% of population)

High school or less

Some college or more

\begin{tabular}{ccc}
1983 & 1985 & 1987 \\
\hline $4 t$ & 41 & 35 \\
59 & 59 & 65
\end{tabular}

IABLE A.4. Occupation (\% of population)

Professional

\begin{tabular}{cc}
1985 & 1987 \\
\hline 25 & 29 \\
16 & 19 \\
25 & 29 \\
11 & 14 \\
23 & 10
\end{tabular}

A.1 
TABLE A.5. Total Annual Household Income (\% of population)

Under $\$ 16,000$
$\$ 16-\$ 30,000$
Over $\$ 30,000$

\begin{tabular}{ccc}
1983 & 1985 & 1987 \\
\hline 26 & 27 & 23 \\
43 & 39 & 33 \\
30 & 35 & 44
\end{tabular}

TABLE A.6. Home Ownership Status (\% of population)

Own home

Rent home

\begin{tabular}{ccc}
1983 & 1985 & 1987 \\
\hline 76 & 71 & 71 \\
24 & 29 & 29
\end{tabular}

TABLE A.7. Length of Stay at Current Residence (\% of population)

1.2 years

3-4 years

More than 5 years

\begin{tabular}{ccc}
1983 & 1985 & 1987 \\
\hline 26 & 33 & 33 \\
16 & 12 & 12 \\
58 & 55 & 55
\end{tabular}

TABLE A.8. Type of Dwelling (\& of population)

Single family

2-4 unit dwelling

More than 4 units

Mobile home/other

\begin{tabular}{ccc}
1983 & 1985 & 1987 \\
\hline 77 & 76 & 76 \\
8 & 9 & 7 \\
8 & 7 & 9 \\
7 & 8 & 7
\end{tabular}

TABLE A.9. Number of Persons in Household ( $\%$ of population)

1 person
2 people
3 people
4 people
5 people
6 people
$7 \cdot 8$ people
9 or more

\begin{tabular}{ccc}
1983 & 1985 & 1987 \\
\hline 15 & 19 & 16 \\
35 & 34 & 33 \\
17 & 17 & 19 \\
20 & 18 & 19 \\
8 & 8 & 9 \\
3 & 3 & 2 \\
2 & 2 & 1 \\
0 & 0 & 1
\end{tabular}


TABLE A.10. Issues Consumers are "Very Concerned" About (\% of population)

Energy conservation Energy use in the home Cost of energy Crime Inflation

Unemployment

\begin{tabular}{ccc}
1983 & 1985 & 1987 \\
\hline 49 & 33 & 44 \\
49 & 35 & 36 \\
70 & 51 & 52 \\
74 & 67 & 62 \\
64 & 53 & 48 \\
63 & 48 & 38
\end{tabular}

TABLE A.11. Energy Conservation Statements Consumers are in Agreement With ( $q$ of population)

Saves money

Enhances home value

Causes price hikes

Eftorts have no effect

Prices not high enough

Don't need to with surplus

Shouldn't ofter consv. prog.

Enhances home comfort

\begin{tabular}{ccc}
1983 & 1985 & 1987 \\
\hline 83 & 92 & 85 \\
24 & 25 & 41 \\
34 & 32 & 27 \\
27 & 22 & 26 \\
- & 8 & 6 \\
- & 4 & 5 \\
- & 13 & 8 \\
- & 91 & 71
\end{tabular}

\section{TABLE 12. Perceptions of Local Electric Utility} (\% of population)

Farniliar with

Favorable impression

Believable info. source

Concerned about customer

Resp, for energy prices

\begin{tabular}{ccc}
1983 & 1985 & 1987 \\
\hline 89 & 96 & 98 \\
73 & 77 & 81 \\
89 & 79 & 87 \\
- & 66 & 76 \\
- & 83 & 87
\end{tabular}

TABLE 13. Perceptions of Bonneville Power Administration (\% of population)

Farniliar with

\begin{tabular}{ccc}
1983 & 1985 & 1987 \\
\hline 65 & 73 & 87 \\
48 & 59 & 69 \\
76 & 66 & 76 \\
- & 52 & 66 \\
- & 77 & 85
\end{tabular}

Favorable impression

Believable info. source Concerned about customer Resp. for energy prices 


\section{A.3 SUPPORTING DATA FOR CHAPTER 4.0}

TABLE A.14. Owner-0ccupied Homes Currently Equipped With Building Shell Enhancements (\% of population)

Weather- proofing

Stm. Thermal pane windows

Bsmt./Fir./Crawlspace insul.

Outside wall insulation

Foot/Attic insulation

Storm / Insulated doors

\begin{tabular}{|c|c|c|}
\hline 1983 & 1985 & 1987 \\
\hline 71 & 82 & 83 \\
\hline 67 & 76 & 80 \\
\hline 55 & 58 & 74 \\
\hline 64 & 86 & 84 \\
\hline 77 & 94 & 95 \\
\hline 62 & 59 & 71 \\
\hline
\end{tabular}

TABLE A.15. Owner-Occupied Homes Currently Equipped With Building Equipment Enhancements (\% of population)

Heat pump

Auto/Setback thermostat

Woodstove / Insert

Water heater solar panels

Heat pump water heater

\begin{tabular}{ccc}
1983 & 1985 & 1987 \\
\hline 11 & 9 & 11 \\
29 & 44 & 62 \\
65 & 39 & 64 \\
- & 2 & 4 \\
- & 3 & 12
\end{tabular}

TABLE A.16. Owner-0ccupied Homes that Indicated it is Likely that Specific Building Shell Enhancements will be Installed in the Next 2-3 Years (\% of population)

Weather- proofing

\begin{tabular}{ccc}
1983 & 1985 & 1987 \\
\hline 37 & 42 & 31 \\
36 & 36 & 35 \\
21 & 17 & 11 \\
18 & 12 & 8 \\
29 & 21 & 12 \\
35 & 36 & 40
\end{tabular}

TABLE A.17. Owner-0ccupied Homes that Indicated it is Likely that Specific Building Equipment Enhancements will be Installed in the Next $2-3$ Years (\% of population)

Heat pump

\begin{tabular}{ccc}
1983 & 1985 & 1987 \\
\hline 14 & 8 & 10 \\
17 & 13 & 30 \\
24 & 15 & 22 \\
- & 9 & 8 \\
- & 6 & 7
\end{tabular}




\section{A.4 SUPPORTING DATA FOR CHAPTER 5.0}

TABLE A.18. Primary Heating Fuels ( ${ }^{6}$ of population)

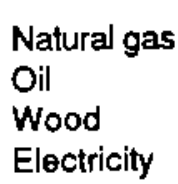

\begin{tabular}{ccc}
1983 & 1985 & 1987 \\
\hline 20 & 20 & 21 \\
11 & 11 & 9 \\
28 & 29 & 22 \\
37 & 38 & 46
\end{tabular}

TABLE A.19. Primary Heating Fuel Adopted by Households that Switched (\%)

Natural gas
Oil
Wood
Electricity

\begin{tabular}{cc}
1985 & 1987 \\
\hline 15 & 19 \\
5 & 8 \\
59 & 46 \\
18 & 27
\end{tabular}

TABLE A.20. Primary Heating Fuel Dropped by Households that Switched ( $\left.g_{6}\right)$

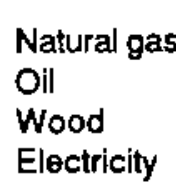

\begin{tabular}{cc}
1985 & 1987 \\
\hline 18 & 13 \\
26 & 18 \\
8 & 19 \\
46 & 47
\end{tabular}

TABLE A.21. Fuel Switching Reasons (* of population)

Expense related

\begin{tabular}{cc}
1985 & 1987 \\
\hline 93 & 70 \\
7 & 30
\end{tabular}

Reliability/Convenience 


\section{A.5 SUPPORTING DATA FOR CHAPTER 6.0}

TABLE A.22. Prospect Group Households (\% of population)

First-Tier

Second-Tier

Non-Prospects

\begin{tabular}{ccc}
1983 & 1985 & 1987 \\
\hline 16 & 14 & 23 \\
43 & 44 & 47 \\
41 & 41 & 30
\end{tabular}

TABLE A.23. Sex by Prospect Group (\% of prospect group population)

Male

Female

\begin{tabular}{ccc|ccc|ccc} 
& \multicolumn{3}{c}{ First-Tier } & \multicolumn{3}{c}{ Second-Tier } & \multicolumn{3}{c}{ Non-Prospects } \\
1983 & 1985 & 1987 & 1983 & 1985 & 1987 & 1983 & 1985 & 1987 \\
\hline 45 & 40 & 44 & 47 & 40 & 48 & 44 & 32 & 32 \\
55 & 60 & 56 & 53 & 60 & 52 & 56 & 68 & 69
\end{tabular}

IABLE A.24. Age by Prospect Group ( $\%$ of prospect group population)

18-24 years

25-34 years

35.44 years

$45-54$ years

55.64 years

Over 65 years

\begin{tabular}{ccc|ccc|ccc} 
& First-Tier & \multicolumn{3}{c}{ Second-Tier } & \multicolumn{3}{c}{ Non-Prospects } \\
1983 & 1985 & 1987 & 1983 & 1985 & 1987 & 1983 & 1985 & 1987 \\
\hline 5 & 7 & 4 & 3 & 6 & 1 & 3 & 2 & 3 \\
33 & 37 & 25 & 23 & 24 & 22 & 19 & 12 & 14 \\
32 & 37 & 39 & 31 & 28 & 35 & 20 & 18 & 11 \\
13 & 11 & 13 & 16 & 20 & 22 & 16 & 17 & 15 \\
12 & 3 & 12 & 14 & 13 & 11 & 19 & 23 & 29 \\
6 & 6 & 7 & 12 & 9 & 11 & 23 & 28 & 28
\end{tabular}

IABLE A.25. Education by Prospect Group ( $\%$ of prospect group population)

High schoof or less

Some college or more

\begin{tabular}{ccc|ccc|ccc} 
& \multicolumn{3}{c}{ First-Tier } & \multicolumn{3}{c}{ Second-Tier } & \multicolumn{3}{c}{ Non-Prospects } \\
1983 & 1985 & 1987 & 1983 & 1985 & 1987 & 1983 & 1985 & 1987 \\
\hline 30 & 40 & 25 & 39 & 39 & 29 & 51 & 48 & 53 \\
71 & 60 & 75 & 61 & 61 & 71 & 49 & 52 & 47
\end{tabular}

TABLE A.26. Occupation by Prospect Group (\% of prospect group population)

Professional

Executive / Administrative

Clerical / Sales / Technical

Crafts / Foreman

Other employed

\begin{tabular}{cc|cc|cc}
\multicolumn{2}{c}{ First-Tier } & \multicolumn{2}{c}{ Second-Tier } & \multicolumn{2}{c}{ Non-Prospects } \\
1985 & 1987 & 1985 & 1987 & 1985 & 1987 \\
\hline 29 & 27 & 28 & 35 & 24 & 23 \\
19 & 22 & 15 & 20 & 16 & 19 \\
22 & 25 & 27 & 27 & 20 & 31 \\
12 & 18 & 9 & 15 & 13 & 17 \\
18 & 8 & 21 & 4 & 28 & 10
\end{tabular}


TABLE A.27. Annual Household Income by Prospect Group ( $\%$ of prospect group population)

Under $\$ 16,000$

$\$ 16-\$ 30,000$

Over $\$ 30,000$

\begin{tabular}{ccc|ccc|ccc} 
& First-Tier & \multicolumn{3}{c}{ Second-Tier } & \multicolumn{3}{c}{ Non-Prospects } \\
1983 & 1985 & 1987 & 1983 & 1985 & 1987 & 1983 & 1985 & 1987 \\
\hline 15 & 13 & 16 & 16 & 15 & 11 & 29 & 35 & 26 \\
44 & 41 & 29 & 46 & 42 & 24 & 43 & 31 & 31 \\
41 & 46 & 55 & 38 & 43 & 65 & 28 & 34 & 44
\end{tabular}

IABLE A.28. Length of Stay at Current Residence by Prospect Group $(\%$ of prospect group population)

$1-2$ years

3-4 years

5 or more years

\begin{tabular}{ccc|ccc|ccc}
\multicolumn{3}{c}{ First-Tier } & \multicolumn{3}{c}{ Second-Tier } & \multicolumn{3}{c}{ Non-Prospects } \\
1983 & 1985 & 1987 & 1983 & 1985 & 1987 & 1983 & 1985 & 1987 \\
\hline 15 & 28 & 22 & 13 & 25 & 27 & 11 & 11 & 9 \\
22 & 9 & 15 & 16 & 12 & 8 & 14 & 10 & 9 \\
63 & 63 & 63 & 71 & 63 & 65 & 75 & 79 & 82
\end{tabular}

TABLE A.29. Type of Owelling by Prospect Group ( $\%$ of prospect group population)

Single family 2.4 unit dwelling More than 4 units Mobile home/other

\begin{tabular}{ccc|ccc|ccc} 
& First-Tier & \multicolumn{3}{c}{ Second-Tier } & \multicolumn{3}{c}{ Non-Prospects } \\
1983 & 1985 & 1987 & 1983 & 1985 & 1987 & 1983 & 1985 & 1987 \\
\hline 90 & 89 & 80 & 91 & 88 & 93 & 85 & 87 & 84 \\
5 & 3 & 4 & 4 & 1 & 3 & 4 & 2 & 2 \\
1 & 2 & 2 & 0 & 1 & 0 & 1 & 0 & 3 \\
5 & 6 & 14 & 5 & 11 & 5 & 11 & 11 & 11
\end{tabular}

IABLE A.30. Size of Household by Prospect Group ( $\%$ of prospect group population)
1 person
2 people
3 poople
4 people
5 people
6 people
7-8 people
9 or more

\begin{tabular}{ccc|ccc|ccc}
\multicolumn{3}{c}{ First-Tier } & \multicolumn{3}{c}{ Second-Tier } & \multicolumn{3}{c}{ Non-Prospects } \\
1983 & 1985 & 1987 & 1983 & 1985 & 1987 & 1983 & 1985 & 1987 \\
\hline 6 & 3 & 8 & 8 & 11 & 12 & 17 & 22 & 20 \\
28 & 23 & 33 & 35 & 32 & 28 & 40 & 42 & 45 \\
22 & 24 & 17 & 19 & 19 & 24 & 15 & 15 & 13 \\
22 & 32 & 28 & 26 & 20 & 21 & 17 & 13 & 16 \\
9 & 9 & 8 & 8 & 11 & 12 & 7 & 5 & 6 \\
7 & 3 & 3 & 2 & 4 & 1 & 3 & 3 & 1 \\
5 & 5 & 1 & 2 & 3 & 1 & 1 & 1 & 1 \\
1 & 2 & 2 & 1 & 0 & 1 & 0 & 0 & 0
\end{tabular}


TABLE A.31. Issues Consumers are "Very Concerned" About by Prospect Group (\% of prospect group population)

\begin{tabular}{lccc|ccc|ccc} 
& \multicolumn{3}{c}{ First-Tier } & \multicolumn{3}{c}{ Second-Tier } & \multicolumn{3}{c}{ Non-Prospects } \\
& 1983 & 1985 & 1987 & 1983 & 1985 & 1987 & 1983 & 1985 & 1987 \\
\cline { 2 - 9 } & 57 & 34 & 53 & 48 & 33 & 33 & 49 & 28 & 41 \\
Energy conservation & 53 & 45 & 43 & 49 & 30 & 32 & 50 & 32 & 26 \\
Cost of ene in the home & 74 & 51 & 60 & 70 & 51 & 42 & 75 & 49 & 59 \\
Crime & 73 & 60 & 61 & 72 & 67 & 54 & 75 & 72 & 71 \\
Inflation & 69 & 51 & 62 & 63 & 53 & 41 & 65 & 57 & 48 \\
Unemployment & 61 & 50 & 51 & 63 & 43 & 29 & 64 & 49 & 37
\end{tabular}

TABLE A.32. Energy Conservation Statements Consumers are in Agreement with by Prospect Group (\% of prospect group population)

\begin{tabular}{lccc|ccc|ccc} 
& \multicolumn{3}{c}{ First-Tier } & \multicolumn{3}{c}{ Second-Tier } & \multicolumn{3}{c}{ Non-Prospects } \\
& 1983 & 1985 & 1987 & 1983 & 1985 & 1987 & 1983 & 1985 & 1987 \\
\cline { 2 - 10 } Saves money & 81 & 90 & 83 & 83 & 92 & 85 & 83 & 93 & 90 \\
Enhances home value & 23 & 25 & 36 & 22 & 21 & 36 & 24 & 25 & 46 \\
Causes price hikes & 34 & 33 & 30 & 35 & 32 & 26 & 38 & 32 & 24 \\
Efforts have no effect & 25 & 14 & 26 & 27 & 20 & 24 & 32 & 28 & 35 \\
Prices not high enough & - & 3 & 7 & - & 8 & 6 & - & 8 & 4 \\
Don't need to with surplus & - & 2 & 2 & - & 5 & 4 & - & 6 & 3 \\
Shouldn't offer consv. prog. & - & 16 & 7 & - & 9 & 5 & - & 17 & 12 \\
Enhances home comfort & - & 98 & 81 & - & 94 & 73 & - & 90 & 63
\end{tabular}

TABLE A.33. Owner-Occupied Homes Currently Equipped with Building Shell Enhancements by Prospect Group ( $\%$ of prospect group population)

\begin{tabular}{|c|c|c|c|c|c|c|c|c|c|}
\hline & \multicolumn{3}{|c|}{ First-Tier } & \multicolumn{3}{|c|}{ Second-Tier } & \multicolumn{3}{|c|}{ Non-Prospects } \\
\hline & 1983 & 1985 & 1987 & 1983 & 1985 & 1987 & 1983 & 1985 & 1987 \\
\hline Weather-proofing & 70 & 79 & 91 & 77 & 85 & 87 & 64 & 79 & 72 \\
\hline Stm. Thermal pane windows & 67 & 69 & 79 & 71 & 81 & 85 & 64 & 74 & 74 \\
\hline Bsmt./Flr / Crawlspace insul. & 65 & 57 & 78 & 62 & 62 & 77 & 43 & 55 & 66 \\
\hline Outside wall insulation & 65 & 83 & 88 & 71 & 88 & 87 & 55 & 85 & 77 \\
\hline Roof/Attic insulation & 82 & 90 & 96 & 83 & 95 & 96 & 70 & 94 & 91 \\
\hline Storm/ Insulated doors & 61 & 48 & 77 & 67 & 58 & 72 & 58 & 63 & 65 \\
\hline
\end{tabular}

TABLE A.34. Owner-Occupied Homes Currently Equipped with Building Equipment Enhancements by Prospect Group (\% of prospect group population)

Heat pump

Auto/Setback thermostat

Woodstove / Insert

Water heater solar panels

Heat pump water heater

\begin{tabular}{ccc|ccc|ccc} 
& First-Tier & \multicolumn{3}{c}{ Second-Tier } & \multicolumn{3}{c}{ Non-Prospects } \\
1983 & 1985 & 1987 & 1983 & 1985 & 1987 & 1983 & 1985 & 1987 \\
\hline 13 & 15 & 13 & 14 & 8 & 15 & 6 & 8 & 3 \\
37 & 45 & 66 & 35 & 48 & 63 & 20 & 39 & 57 \\
71 & 46 & 61 & 69 & 42 & 67 & 59 & 33 & 60 \\
- & 1 & 6 & - & 3 & 4 & - & 1 & 3 \\
- & 5 & 13 & - & 3 & 15 & - & 1 & 5
\end{tabular}


TABLE A.35. Owner-Occupied Homes That Are Likely to Install Specific Building Shell Enhancements in the Next 2 to 3 Years, by Prospect Group (\% of prospect group population)

\begin{tabular}{lccc|ccc|ccc} 
& \multicolumn{3}{c}{ First-Tier } & \multicolumn{3}{c}{ Second-Tier } & \multicolumn{3}{c}{ Non-Prospects } \\
& 1983 & 1985 & 1987 & 1983 & 1985 & 1987 & 1983 & 1985 & 1987 \\
\cline { 2 - 10 } Weather- proofing & 91 & 76 & 72 & 58 & 51 & 31 & 4 & 20 & 0 \\
Stm./Thermal pane windows & 86 & 85 & 81 & 51 & 53 & 47 & 4 & 1 & 0 \\
Bsmt./Flr./ Crawlspace insul. & 53 & 42 & 28 & 38 & 21 & 10 & 0 & 3 & 0 \\
Outside wall insulation & 57 & 32 & 26 & 25 & 13 & 4 & 0 & 0 & 0 \\
Roof/Attic insulation & 82 & 45 & 37 & 53 & 25 & 8 & 1 & 8 & 0 \\
Storm/Insulated doors & 88 & 69 & 80 & 50 & 51 & 53 & 2 & 1 & 4
\end{tabular}

IABLE A.36. Owner-0ccupied Homes That Are Likely to Install Specific Building Equipment Enhancements in the Next 2 to 3 Years, by Prospect Group ( $\%$ of prospect group population)

Heat pump

Auto/Setback thermostat Woodstove / Insert Water heater solar panels Heat pump water heater

\begin{tabular}{ccc|ccc|ccc} 
& First-Tier & \multicolumn{3}{c}{ Second-Tier } & \multicolumn{3}{c}{ Non-Prospects } \\
1983 & 1985 & 1987 & 1983 & 1985 & 1987 & 1983 & 1985 & 1987 \\
\hline 46 & 28 & 24 & 15 & 10 & 11 & 1 & 0 & 0 \\
45 & 56 & 63 & 25 & 14 & 35 & 1 & 0 & 0 \\
69 & 48 & 58 & 35 & 22 & 17 & 2 & 0 & 0 \\
- & 33 & 23 & - & 10 & 6 & - & 0 & 0 \\
- & 25 & 20 & - & 6 & 4 & - & 0 & 2
\end{tabular}



APPENDIX B

SAMPLE WEIGHTS 
APPENDIX B

SAMPLE WEIGHTS

This appendix presents the sample weights applied to results of each survey. Note that the Phase II survey included a split-run question structure. For those respondents asked split-run questions, a unique sample resulted. Table B.3 presents the weights for this sample.

The population of counties within each of the four geographic regions were determined first, then summed, which yielded a total population count for each region. The populations of each region were then expressed as a percentage of the total population of the BPA service area. The weights were determined by comparing the sample observations for each region with their respective divisional populations. All population data were approximated by using the 1980 Census data.

TABLE B.1. Phase I Sample Weights

\begin{tabular}{|c|c|c|c|c|c|}
\hline $\begin{array}{l}\text { Geographic } \\
\text { Division } \\
\end{array}$ & $\begin{array}{c}\text { Relative } \\
\text { Weight } \\
\end{array}$ & $\begin{array}{l}\text { Percent } \\
\text { of Total } \\
\text { Households } \\
\end{array}$ & $\begin{array}{l}\text { Households } \\
\text { in Division } \\
\end{array}$ & $\begin{array}{l}\text { Households } \\
\text { in Sample } \\
\end{array}$ & $\begin{array}{c}\text { Population } \\
\text { Weight for } \\
\text { Division } \\
\end{array}$ \\
\hline W. Washington & 1.58 & 39.50 & $1,193,884$ & 500 & 2387.77 \\
\hline W. Oregon & 1.12 & 28.00 & 846,297 & 500 & 1692.59 \\
\hline $\begin{array}{l}\text { E. Washington } \\
\& \text { N. Idaho } \\
\& \text { W. Montana }\end{array}$ & 0.73 & 18.25 & 551,604 & 500 & 1103.21 \\
\hline $\begin{array}{l}\text { E. Oregon } \\
\text { \& S. Idaho }\end{array}$ & $\underline{0.57}$ & 14.25 & 430,705 & 500 & 861.41 \\
\hline TOTAL & 4.00 & 100.00 & $3,022,490$ & 2,000 & -- \\
\hline
\end{tabular}


TABLE B.2. Phase II Sample Weights

\begin{tabular}{|c|c|c|c|c|c|}
\hline $\begin{array}{l}\text { Geographic } \\
\text { Division } \\
\end{array}$ & $\begin{array}{l}\text { Relative } \\
\text { Weight } \\
\end{array}$ & $\begin{array}{l}\text { Percent } \\
\text { of Total } \\
\text { Households } \\
\end{array}$ & $\begin{array}{l}\text { Households } \\
\text { in Division }\end{array}$ & $\begin{array}{l}\text { Households } \\
\text { in Sample } \\
\end{array}$ & $\begin{array}{l}\text { Population } \\
\text { Weight for } \\
\text { Division } \\
\end{array}$ \\
\hline W. Washington & 1.58 & 39.50 & $1,193,884$ & 258 & 4627.46 \\
\hline W. Oregon & 1.12 & 28.00 & 846,297 & 270 & 3134.43 \\
\hline $\begin{array}{l}\text { E. Washington } \\
\& \mathrm{~N} \text {. Idaho } \\
\& \text { W. Montana }\end{array}$ & 0.73 & 18.25 & 551,604 & 274 & 2013.15 \\
\hline $\begin{array}{l}\text { E. Oregon } \\
\& \text { S. Idaho }\end{array}$ & $\underline{0.57}$ & 14.25 & 430,705 & $\underline{256}$ & $\underline{1682.44}$ \\
\hline TOTAL & 4.00 & 100.00 & $3,022,490$ & 1,058 & -- \\
\hline
\end{tabular}

TABLE B.3. Phase II Split-Run Question Sample Weights

\begin{tabular}{|c|c|c|c|c|c|}
\hline $\begin{array}{l}\text { Geographic } \\
\text { Division }\end{array}$ & $\begin{array}{l}\text { Relative } \\
\text { Weight } \\
\end{array}$ & $\begin{array}{l}\text { Percent } \\
\text { of Total } \\
\text { Households } \\
\end{array}$ & $\begin{array}{l}\text { Households } \\
\text { in Division }\end{array}$ & $\begin{array}{l}\text { Households } \\
\text { in Sample }\end{array}$ & $\begin{array}{l}\text { Population } \\
\text { Weight for } \\
\text { Division }\end{array}$ \\
\hline W. Washington & 1.58 & 39.50 & $1,193,884$ & 108 & 11054.48 \\
\hline W. Oregon & 1.12 & 28.00 & 846,297 & 91 & 9299.97 \\
\hline $\begin{array}{l}\text { E. Washington } \\
\& \mathrm{~N} \text {. ldaho } \\
\& \mathrm{~W} \text {. Montana }\end{array}$ & 0.73 & 18.25 & 551,604 & 93 & 5931.23 \\
\hline $\begin{array}{l}\text { E. Oregon } \\
\& \text { S. Idaho }\end{array}$ & $\underline{0.57}$ & 14.25 & 430,705 & 80 & 5383.81 \\
\hline TOTAL & 4.00 & 100.00 & $3,022,490$ & 372 & -- \\
\hline
\end{tabular}

TABLE B.4. Phase III Sample Weights

\begin{tabular}{|c|c|c|c|c|c|}
\hline $\begin{array}{l}\text { Geographic } \\
\text { Division }\end{array}$ & $\begin{array}{l}\text { Relative } \\
\text { Weight }\end{array}$ & $\begin{array}{l}\text { Percent } \\
\text { of Total } \\
\text { Households } \\
\end{array}$ & $\begin{array}{l}\text { Households } \\
\text { in Division }\end{array}$ & $\begin{array}{l}\text { Households } \\
\text { in Sample }\end{array}$ & $\begin{array}{l}\text { Population } \\
\text { Weight for } \\
\text { Division } \\
\end{array}$ \\
\hline W. Washington & 1.58 & 39.50 & $1,193,884$ & 126 & 9475.27 \\
\hline W. Oregon & 1.12 & 28.00 & 846,297 & 127 & 6663.76 \\
\hline $\begin{array}{l}\text { E. Washington } \\
\& \mathrm{~N} \text {. Idaho } \\
\& \text { W. Montana }\end{array}$ & 0.73 & 18.25 & 551,604 & 125 & 4412.83 \\
\hline $\begin{array}{l}\text { E. Oregon } \\
\& \text { S. Idaho }\end{array}$ & $\underline{0.57}$ & 14.25 & 430,705 & $\underline{125}$ & $\underline{3445.64}$ \\
\hline TOTAL & 4.00 & 100.00 & $3,022,490$ & 503 & -- \\
\hline
\end{tabular}


APPENDIX C

IESTING PROCEDURE AND TEST RESULTS 
APPENDIX C

\section{TESTING PROCEDURE AND TEST RESULTS}

This appendix explains the application of the Chi-square test with regard to evaluating the significance between differences in the Phase I (1983), Phase II (1985), and Phase III (1987) survey samples. The Chi-square test is utilized because of the nominal and ordinal characteristics of the data collected. The null hypothesis is that differences between observed and expected responses over different time periods (with respect to the classification of responses), are not significant. The significance level accepted is $5 \%$ (denoted with an "A") and $10 \%$ (denoted with a "B"). Test results like this, for each characteristic discussed in the report or shown in a table of Appendix $A$, are presented in Table C.1. For example, if a $5 \%$ significance level occurs, the null hypothesis will be rejected implying that responses during one time period are significantly different from those of a different time period. An empty cell in the table reflects that either the test was unreliable due to a small "expected" value frequency or that the null hypothes is is supported. Although a specific test may indicate independence between the categories being tested, an associated table and figure may still appear in either the body of the report or in Appendix A. Note that the graphical and tabular results were weighted to represent population values while the statistical tests are based on sample sizes. For a more formal discussion of the Chi-square test refer to Siegal (1956). 
TABLE C.1. Chi-Square Test Results

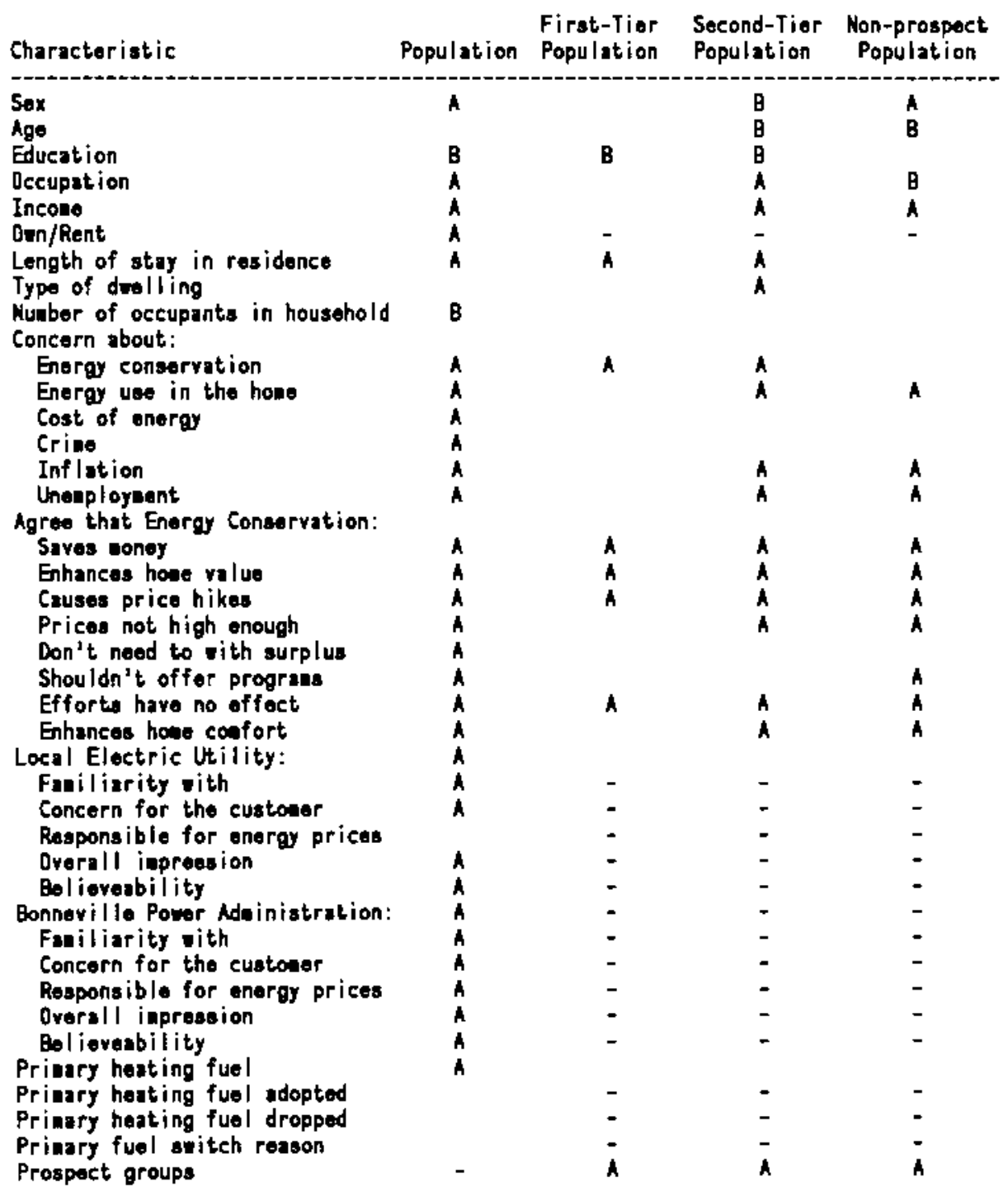


TABLE C.2. Chi-Square Test Results For Installed Building Shell and Equipment Enhancements

\begin{tabular}{|c|c|c|c|c|}
\hline \multirow[b]{2}{*}{ Charactoriatic } & \multicolumn{4}{|c|}{ Currently Installed } \\
\hline & Population & $\begin{array}{l}\text { First-Tior } \\
\text { Population }\end{array}$ & $\begin{array}{l}\text { Socond-Tior } \\
\text { Population }\end{array}$ & $\begin{array}{c}\text { Non-prospect } \\
\text { Population }\end{array}$ \\
\hline $\begin{array}{l}\text { Weatherproofing } \\
\text { Stern/Theraal pane sindows } \\
\text { Heat punp }\end{array}$ & $\hat{A}$ & $\hat{\mathrm{B}}$ & $\hat{\hat{A}}$ & $\hat{A}$ \\
\hline Autonatic/setback thermostat & $h$ & A & $A$ & A \\
\hline Bsut./Floor/Cravlapace insul. & $A$ & A & $A$ & A \\
\hline Qutside roll insulation & A & $A$ & A & A \\
\hline Roof/Attic insulation & $A$ & A & A & A \\
\hline Solar wator haater & $A$ & & & \\
\hline Stora/Insulated doors & $A$ & $A$ & A & \\
\hline Woodstove/Furnace & A & A & A & $A$ \\
\hline Heatpunp vater heater & A & B & A & \\
\hline
\end{tabular}

TABLE C.3. Chi-Square Test Results For Intended Investment in Building Shell and Equipment Enhancements

Intended Investaent.

\begin{tabular}{|c|c|c|c|c|}
\hline \multirow[b]{2}{*}{ Charactor istic } & \multicolumn{4}{|c|}{ Intended Investaent. } \\
\hline & Population & $\begin{array}{l}\text { Firat-Tior } \\
\text { Population }\end{array}$ & $\begin{array}{l}\text { Socond-Tiar } \\
\text { Population }\end{array}$ & $\begin{array}{l}\text { Non-prospect } \\
\text { Populat i on }\end{array}$ \\
\hline $\begin{array}{l}\text { Ieatherproofing } \\
\text { Stora/Theralal pane vindows }\end{array}$ & 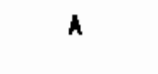 & $\boldsymbol{A}$ & $A$ & A \\
\hline Hoat punp & $A$ & A & A & \\
\hline Autonatic/oetback thernostat & A & & $A$ & \\
\hline Bent./Floor/Cravlspace insul, & A & $A$ & $A$ & \\
\hline Dutside mil ingulation & $A$ & h & A & \\
\hline Roof/Att ic insulation & A & $\boldsymbol{A}$ & $\ddot{A}$ & $A$ \\
\hline $\begin{array}{l}\text { Stora/Insulated doors } \\
\text { Toodstove/Furnace } \\
\text { Hoatpunp nuter heater }\end{array}$ & $A$ & A & $A$ & \\
\hline
\end{tabular}





\section{REFERENCES}

RMH Research Inc. 1984. Marketing Environment for Energy Conservation in the Pacific Northwest, prepared for the Pacific Northwest Laboratory by RMH Research, Inc., River Edge, New Jersey.

Siegel, S. 1956. Nonparametric Statistics. McGraw-Hill Co., New York, New York. 


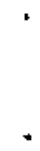




\section{BIBLIOGRAPHY}

Fang, J. M., Hattrup, M. P., Nordi, R. T., and Shankle, S. A. 1987. Household Energy Conservation Attitudes and Behaviors in the Northwest: Tracking Changes Between 1983 and 1985. PNL-5892, Pacific Northwest Laboratory, Richland, Washington. 


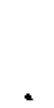


PNL -6572

UC-95d

\section{DISTRIBUTION}

No. of

Copies

30

L. Saito

Bonneville Power Administration - RMRB

1002 N.E. Holloday Street

P.0. Box 3621

Portland, OR 97232

T. 0liver

Bonneville Power Administration - RMCC

1002 N.E. Holloday Street

P.0. Box 3621

Portland, OR 97232

K. Keating

Bonneville Power Administration

- RPEB

1002 N.E. Holl loday Street

P.0. Box 3621

Portland, OR 97232

R. Gilman

Bonneville Power Administration - RPA

1002 N.E. Holloday Street

P.0. Box 3621

Portland, OR 97232

C. Whitney

Bonneville Power Administration

- RMRB

1002 N.E. Holloday Street

P.0. Box 3621

Portland, OR 97232

$P$. Durocher

Bonneville Power Administration

- RMRB

1002 N.E. Holl loday Street

P.0. Box 3621

Portland, OR 97232
No, of

Copies

G. Ferguson

Bonneville Power Administration

- RMRC

1002 N.E. Holloday Street

P.0. Box 3621

Portland, OR 97232

J. Deherrera

Bonneville Power Administration - RMRC

1002 N.E. Holloday Street

P.0. Box 3621

Portland, OR 97232

F. Peterson

Bonneville Power Administration - RPEE

1002 N.E. Hol loday Street

P.0. Box 3621

Portland, OR 97232

F. Abel

Office of Building and Community Services

U.S. Department of Energy

Washington, DC 20585

10 Office of Scientific and

Technical Information

\section{ONSITE}

DOE Richland Operations office

J. J. Sutey 
No. of

Copies

20 Pacific Northwest Laboratory

R. W. Schultz (10)

B. M. Bailey

R. 0 . Weijo

S. A. Harkreader

Publishing Coordination MH (2)

Technical Report Files (5) 